The horns: symbol of power

An iconographical study in Mesopotamian Art

\title{
The horns: symbol of power An iconographical study in Mesopotamian Art
}

\author{
Inass Mostafa Abd Elmohsen \\ faculty of Archeology -Aswan University \\ DR.HOSNY27N@YAHOO.COM
}

\begin{abstract}
The horns play an important role in the civilizations of the ancient Near East, and in Mesopotamia in particular, where man considered them a symbol of strength and fertility because the animals that possessed them were characterized by these qualities. By the time the man borrows this animal part to indicate his strength as a human. Many modern civilizations believe that the presence of horns on the head point to a primitive demonic origin, while in Mesopotamia it was considered to be a divine and sacred origin.
\end{abstract}

Keywords: Horns -qarnu -Ibex - bull man- Apkallu - bull- moon horn

\section{Introduction}

Horns play an important role in religious symbolism and art for reasons that go back to a primitive stage of thoughts and early human observations to the use of horns by animals possessing them.

There was also a period in human history when he made use of horns as weapons or tools. during the Stone Ages and also into the Bronze age, harpoons, picks, wedges, chisels ...etc.

by time Myth and art retained for the gods some part of the animal, head, hoofs, wings, horns but the last one was also a symbol of power, naturally retained for the powerful god in many civilizations such symbols were given to gods with animal past but here such symbols of strength may have been given to a divine or semidivine who had no animal past.

the texts and iconography concerning (horns) are hundreds and even thousands so we had to select the material carefully to cover most of the topics of the research

\section{1-The terms for horn}

1-1 The Sumerian term si means horn which used as fallow:

\section{1-1-1As a part of the natural animal}

1- si ...horn

-OB tablet from Nippur in Hilprecht Collection, University of Jena, Germany nos. HS 0239, HS 0250, HS 0256 
(Hilprecht.1906:no37 ;Thompson.1904: vol 19 .pl 12.k 4143, pl. 30-32, K 4352 ;Landsberger .1967: MSL9, nos. 124-137 o v i 9)

si i $\boldsymbol{i l}_{2}-\boldsymbol{l a}_{2}$ (raised horns) (Mark .2008: no 130, o2)

2-maš ${ }^{2} . .[s i]$...du ( goat with horn)

-ED IIIa (ca. 2600-2500 BC) tablet from Tell Abu Salabikh in the National Museum of Iraq, Baghdad, Iraq (Biggs. 1974:. No 28 Abs-T 242,O iii 8. )

uzud si ..yar.. (Female goat with a horn)

(Chiera. 1929: vol 1 no. 44, oii 23,24)

3- gud si min yal $_{2}$ (ox with two horns) (Kienast, B, 1978: Bd 2 ,p215)

4- us si $\mathrm{mu}_{2}-a$ ( ewe growing horns ) (Chiera, 1929: vol 1 no. 37, 46 ; Draffkorn \& Gordon. 1960/ 1 Part B: Tablet XIII, no. 81 V04)

4- $a_{2}$ si yal2-la-, ..ab si... [yal $_{2}$-la] (cow with horns)

-OB tablets from Nippur in the University of Pennsylvania Museum of Archaeology and Anthropology, Philadelphia, Pennsylvania, USA no N 5547, UM 29-16-202, UM 29-16-207, UM 29-16-513, N 1527 ,CBS 06463 , N 5763

Draffkorn \& Gordon. 1960: Part B: Tablet XIII. No81.v4,19. O iii 11,34 no. 82 V34.r10/v 58 r ii 3,

- OB tablet from Nippur in the University of Pennsylvania Museum of Archaeology and Anthropology, Philadelphia, Pennsylvania, USA CBS 06073

(Chiera, E, 1929. vol 1 no. 215 r i 17)

5- .udu.. si yar / udu si gar $/$ / udu si $e_{3}$ (sheep with a horn)

-Neo-Babylonian table in the metropolitan museum of art no MMA 86.11.121

(Spar \& Lambert. 2005: Vol II no 55 r i6 a)

-Neo-Babylonian tablet from kish in the Ashmolean Museum Ashm 1924-0786 ; Ashm 1924-0844 ; Ashm 1924-1888 ; Ashm 1924-2266

(Van Der Meer .1939: Vol. 6/. 2 no.175-176, 76, oiii46)

-Neo Assyrian tablet from Assur (Qalat Sherqat) in the Vorderasiatisches Museum, Berlin, VAT 14275

(Landsberger, 1960: MSL 08/1 E,5, VAT 14275)

6-am si $e_{3} \quad$ wild bull whose horns have appeared (NA)

-Neo -Babylonian tablet in the BM no. 054203 (Gesche, 2000:no387, r4-6, BM 054203)

-Neo Assyrian tablet from Assur in the VORDERASIATISCHES MUSEUM, BERLIN, GERMANY MUS no, (40) VAT 11517. (Matouš.1933: Bd1, no.40 /oi51 ;52 .45/o i $13,14,15,16$ )

\section{1-1-2- As a part of mythical creature}

1-muš si gurз..ru horned viper

-OB tablet from Nippur in the University of Pennsylvania Museum of Archaeology and Anthropology, Philadelphia, Pennsylvania, USA CBS 06434

(Chiera.1929: Vol 1 no. 51 ; Landsberger,1960:MSL 8/1. Tablet XIII..no 82 V29)

2- muš ..ušumgal.. Dragon = mythical snake, horned viper 
The horns: symbol of power

\section{An iconographical study in Mesopotamian Art}

-Neo Assyrian tablet from Assur in the Vorderasiatisches MUSEUM, BERLIN, GERMANY . NO VAT 10706 ( Matouš, 1933 Bd1, no.40 o i 18-19/41 o 6 /44 o i $6,18)$

\section{1-1-3As a part of the gods}

*Unakkip nakrëja ina si.MEš-̌̌a gašrăti

(Ninlil the wild cow) gores my enemies with her strong horns

(STRECK, 1916: II .no 78 ix 78)

*Bèl si. MEš- ša ukarrit Bel cut off her (Tiamat s) horns (Ebeling, 1919: no307 r 13)

*(Nergal) nă̌̌s SI.MĚ̌ eddèti ( Böllenrücher.196:no 50:3)

*(Nergal) am-ma-az-za-ba-Ši-qub-bé-en si-gal-zu bi-tux

You are standing like a wild bull; your great horn has smitten them (line 49) (Sjöberg.1973-74: p4)

*(Ninurta) am a $a_{2}$ huš $i l_{2}-i l_{2}$ "Wild bull raising the fierce horns." (Pfitzner.2019: p159)

\section{1-1-4As a part of the statues of the gods or the animal}

*Kisitte qar-ni-šu-nu ša şarpi [a] ppi qar-ni-šu-nu ša hurăşi

The base of their (animal's) horns is of silver the tip of their horns of gold (Köcher.1957: p. 302.kol i.20)

*qar-na-šu-nu u ildi qar-ni-šu-nu ina 9- TA. ÀM ţurri ša h̆urăşi ahhuza

their horns are of black wood, their horns and the bases of their horns are mounted with nine gold bands each (Köcher.1957: p.306, kol iv, 10)

\section{1-1-5 as manufactured objects:}

*...̌̌a si udu.MĚ̌ .. made of sheep's horn (Knudtzon .1978: no25, iii 33)

${ }^{*} \boldsymbol{s i}^{\text {? }} \mathbf{k u g}$ sig $_{17} \quad$ Golden horn (Civil .2010:no3,2,13)

\section{1-1-6As a part of moon}

*Šumma sin si.ME ̌̌ -Š́́ kíma qaŠti

If the horns of the moon look like a bow. (Virolleaud, 1909: sin 6:7)

\section{1-1-7As a medication}

* Si alpi ša šumèli si ajali turrar

You char the left horn of an Ox and a deer horn

(Köcher.1971: no .216:46;Biggs. 1967:no 56 iv 3)

* Si alpi ša imitti si MÀšša šumèli You char the left horn (Thompson. 1923: no.102,lin38)

\section{1-2 Qarnu:}


Another term from the Akkadian period qarnu means horn used in various cuneiform texts from old Assyrian and old Babylonian right down to the neoAssyrian and neo-Babylonian periods.

the (qarnu ) is used for both the horns of animals and the cusp of the moon, usually referring to the horns of celestial bodies, such as the moon and Venus, as well as to the visible part of the moon's and sun's disk during an eclipse .( CAD, 'Q', n137138 , under qarnu 3 )

We find it in a text from the Srgonic period and from a later time. a classical example from the text (Legand of Naram- Sin) qá-ar-na-a-am "Horn "

( Güterbock;Weidner \& Pinches: 1934. p 46 ,lin7 trans p.47 )

*a a 2 qar-[nu] horn

Neo- Assyrian tablet from Nineveh in the BM Acc K 00005

(Campbell. 1904: Part XIX ,pl. 30-32, K 00005: r i 2/ K 04352: r i 10; r i 12/ pl. 12, K 04143: r i 2)

*248-28-31 Šum-ma a-wi-lum alpam i-gur-ma qarni-šu iš-bi-ir

If a man hire an ox and break its horn or cut off its tail

*251-52-58 šum-ma alap a-wi-lim na-ak-ka-a[m-ma] ki-ma na-ak-ka ${ }^{b}$ pu-u baab-ta-šu u- še-di-šum-ma qar-ni-šu la u-šar-ri-im

"If a man's bull has been wont to gore and they have made known to him His habit of goring, and he have not protected his horns or have not tied it up" (Harper.1904:no248-28-31/251-52-58)

Apparently that the Akkadian qarnu has the same meaning of the Sumerian $\mathbf{S i}$ and also used with the literal-extended meaning

\section{2-The representing of the horned natural animal:}

It is interesting to realize that the interest in depicting the horns motif began in the most primitive periods where the artist distinguishes between horned animals, from the shapes of the horns and their directions.

ending with the belief that the horns represent the power and divinity to be placed on the heads of gods and kings.

The natural physical power and reproductive potency of horned animals, like bull, ibex, goat...etc. were so important for the economy of ancient hunting and agricultural societies. It was also a part of the surrounding environment that made them ideal symbols of strength and fertility. The association of horns with fertility was further encouraged by their phallic shape 


\section{2-1 Ibex}

The use of the terms enzu and turāhu in Akkadian texts differentiate the between domestic and wild mountain goats. another Akaddian word,sappāru points to the wild goat.(Albenda 2008:p 70)

The genus Capra (goats and ibexes) is composed of up to nine species. Five of these are ibex,of which the Alpine ibex (Capra ibex) and Nubian ibex (Capra nubiana) are the most likely to have inhabited parts of the ancient Near East.

The ibex of the high mountains was very familiar to be represented repeatedly it may be confused with the mountain sheep, from the shape of its horns, but it has a beard, which neither the sheep nor the oryx has. There is another wild goat of the mountains known as the Capra vgagrus, which has very long horns reaching over its back, less angular and looks thick and sweep back like curve; they are flattened underneath, and on the upper surface are ornamented by several protuberances inclined backward and extending across the whole width of the upper surface like ribs. The ibex was also perhaps (ayalum) in Babylonian, The Sumerian is (si-mul), which means star-horn or bright-horn(fig.1) .(Ward 1910: p416; Van Burne 1939: p50)

The ibex was revered for its medical properties, although it is uncertain how early they were known. And maybe seals depicting the ibex were used as amulets to protect from poisonous snakes,so the animal was hunted for the secretions produced in its stomach, which are a natural antidote to certain poisons, particularly that of the viper. (Gane,2012:p145;Root2002:p184)

A painted Powel from Samarra is now in the Berlin museum. AV13408 represents the ibex in a geometric shape with a little Crosse marks in the horns. (fig no. 2), And on a painted piece of pottery from Ubeid found in Tello (Girsu) now in louver museum no.AO 15311 (fig no. 3)

seals are showing the ibex in herds or with other animals in well composed scenes. (Frankfort.1939:plIV-m;pl V-f $\quad$;Frankfort.1955:nos $\quad .15(\mathrm{kh} . \mathrm{VII} .27 \quad 8) \quad, 39(\mathrm{kh}$ VII.94); Von der osten,1936:pl II no16; De clereq 1.pl III .no 27 ;Legrain 1936:nos.274,277;De Laport 1923:II .pl 90.fig 7; Dalley. 1972: pl.XLIX no.4,7;Meek.1944:no 3; Eisen,1940:nos 15; Moortgat,1969:pl.I-4)

and also as a part of a nutrel scene with branches and leaves (Legrein 1936:nos. 191.202,203,204,263;Frankfor1939:plVI-d,I;DeLaport,1923:pl.89fig13.;

Buchana1981:no209,Eisen1940:no6,27;Moortgat,1969:plF-7) (fig .4 ).

The theme of the eagle and two-horned ibexes is common from the period of Jemdet Nasr to early dynastic . in the early dynastic III the bird was in many cases 
the lion-headed eagle such a theme can be clearly seen on the silver Vase of Entemena from Lagash. And on many seals from different periods

(VA.07954,BM119201)(Ward,1910:nos.57-59,62,62-65,68,69,71,82 ,118; Von der osten ,1934: nos 39,44,46,51,52;Von der osten,1936: no.27 ;Buchanan .1981 :nos.283,285,287;Boehmer.1965nos.83,86,87;Amiet,1980:no.1790;Amiet,1961:no1 453;Collon1982:nos.284,321,323, 239; Munn-Rankin,1959: no.4; Wiseman 1962: (p.18, pl.15h) , (p.26, pl. 22c) , (p.30, pl.26e),(p.33, pl.29e), (p.30, pl.26c) ;Wiseman1959:no.24;Declarq,1888:nos 10,12,17;Legrein1936:no37;Legrein .1951:URX,nos111,114, 117,122,128; Woolley,1934:pls 97-a, b,98-c, pl100c,pl104-35,37, , pl 192, nos.87-90 ,pl199, Moortgat,1969:pl. M-1) (fig 5)

The best representations of ibex from Larsa exist in Louvre AO15705.

it consists of two worshiper carrying a pedestal on it stands three ibexes back to back their horns seem to interlock and their heads covered with gold-leaf (Van Buren.1939: p53) (fig.6)

and From the royal cemetery of Ur squares of shell decorated the faces of the gaming -boards show the representation of the ibex reversed and attacked by lions (Woolley, 1934: Ur II. Pls. 97,98, 100.c, no8 pl 198,49pl-19,56-60, 63,64 ; Boehmr .1965: nos. 44-46,57,60-62) (fig.7)

such scene was verey commen and repeted from many periods as seen in many seals (Dalley.1972: nos 8,9,10, plXLIX; Ward,1910:figs.99,112-118 202 ;Legrein,1936:nos,230,252,255,256,546;Legrein .1951:UR X,no 86)

The ibex was a part of the heroic contest scenes whether it with Gilgamesh and Eabani, or under the attack of the hunters or under the protection of the defender heroes(Ward,1910:nos114,146,169,170,418;Legrein1936:nos.252,256,287

;Legrein.1951:nos.170,172,173,176,179;Delaport.1923:II,pl.65,fig14;Declarq .1888.nos ,40,41,67)

And according to their magical and sacred powers they connected with shrines and temples in usual representation where we can see the doors of the shrines (in many cases it was double) and the ibexes in front of the doors, and their mysterious connection to the gods allow them to appear in offering and worshipping scene whether they were behind the god as a part of the scene or rampant on the god lap or laying under his feet

(Frankfort.1939:pl IIV-d,g,I; Ward,1910: nos.484-492;377; De Clercq,1888 :no 2;VonderOsten.1934:nos.24,25,27,28;Buchanan,1981:nos.162,168;Amiet ，1961 :nos 382,390,393,625;Amiet,1980:no.1777) (fig.8)

And in some cases, we see it in the hands of the protective spirits Apkallu like the representation In the northwest palace of Ashurnasirpal II at Nimrud two Apkallu one of them carrying in his hand ibex (LAYARD .1853: PL35) (fig.9) 
The tree-and-ibex motif is quite common on objects from the Royal Cemetery at Ur (Woolley.1934: nos.91,121-122,264,276-277, pIs.87-89 ,96 ,97,100,115, Eisen,1940:nos 98,99).(fig.10)

It is also apparent, although articulated somewhat differently, on an Early Dynastic 11-Ill cosmetic container from Nippur, on a tablet from Fara (Shuruppak), on Old Babylonian terracotta. (Hansen1998: 49, 60-62, nos. 6, 8; Barrelet 1968, no. 849; Van Buren 1930: nos. 863-864; Opificius 1961: nos. 675-676; Parrot 1958: p27-28, fig. 23)

Two realistic representations to ibex in one of them it featuring its four feet as if it were going to jump and in the other it stands, and on the other standing on its hind feet with its front feet raised. (Delaport 1923: A708, A 786)

Chasing ibex displayed in the fourth panel on the white Obelisk of ashurnasirpal I (Moortgat 1969:123-25.pl 251;Reade 1975:pl 31a)

And the ibex also appears as a filling motif in the Brick panel of Shalmaneser III from Fort Shalmaneser at Nimrud (Iraq), kneeling on one knee before a big rosette. (Fügert.A \& Gries .H. 2020:fig 3 p4)

\section{2-2Antelope:}

The Antelope was a well-known animal and often appears on the cylinders, although it is not always easy to distinguish it from the wild or the domesticated goat. (Ward 1910: p416)

(Antilope cervicapra) the numbers of antelope representations in archaic art prove that the animal was a part of the surrounded environment at least in early periods. and it seems that there was more than one kind. one of them has horns that sweep straight backward and others their horns stretch back horizontally and downward curve it was not easy to distinguish between the antelope and ibex but we determined that the ibex was bearded and the antelope beardless. (Van Buren. 1939: p43) (fig.11)

The antelope appears in similar scenes to ibex. With other animals in wellcomposed scenes or as a part of the contest scenes or as a part of the herd or attacked by lions (Woolley.1934 :UrII. Nos.71,91,131,154,156,160,206,217,279 ;Legrein. 1936: UR III. Nos.20, 186 ,187, 190-195,200 ,201, 224, 227, 229,232,233,236,238,242,245,252,254,257,252,254,257;Legrein.1951:nos83,84 ,123,135,140,150,154,166,167,168,173,177,181,552;VonderOsten.1934:nos. 78,90,91;Ward.1910.nos.94,118;Meek.1944:no4;Mackay.1929:plXLI.nos1,2 ,13,14,16;plXLII.nos.1576,1900,2014,2162,2214,2432,2515,2567,2615,2883 ;Buchanan.1981:nos.170175,190,236,259,291,297,306,307,372) (fig.12)

\section{2-3Gazelle: şabitu}

many kinds of gazelles are known in Mesopotamia they vary in the shape of horns, some have lyrate horns, others have straight ones and some have ringed horns, and 
the females of some species have short horns, others show no trace for horns.

(fig.13)

the common species in Mesopotamia are Gazella. Dorcas, marica, subgutturosa , and Arabica other species have been recorded ,but they may be local variants of recognized species that what it makes easy to understand why the horns are drawn in different ways .(Van Burne,1939:p46)

Gazelle representations are rare and ambiguous in Mesopotamian visual art, and in many cases, it is difficult to establish whether the portrayed species is a bull, an ibex or a gazelle.

the diadem of Pu'abi from Royal Cemetery of Ur, on which the golden figures of gazelles and deer (fig.14) (Woolley 1934: p89, 565, Pls 140-141)

A middle Assyrian Pyxis shows two gazelles flanking a tree and two date palms, the two gazelles turn in opposite directions. (Haller. 1954: abb161, p153) (fig .15)

From Tell Asmar, a statue of the god of fertility appears on its rounded base. From the back, an engraving of an eagle grasping two gazelles and surrounded by leaves (Frankfort ,1935: p.55, fig 64) (fig.16)

A clay terracotta plaque from Larsa represents the winged naked goddess stands with her birdy feet upon two gazelles. (Van Buren, 1930, no. 458) (fig.17)

On seals Gazelle appears among other animals in the familiar scenes to the antelope and ibex whether it was in the field or in the hunting scene (Von derOsten.1936:pl. IIno.16;Lagrein,1936:nos.212,246,384;Delaporte ,1923 : no. A77 ; Legrain.1951:no.85)( fig.18) .The usual scene of lion attacked horned animal here it was gazelles (Munn-Rankin.1959 :p21.no4 ;Collon ,1982: nos .49,54,55; Legrain .1951nos.171,517)(fig.19)

Even the scenes of the conflict, the Gazelle was part of it (Von der Osten.1934:no102; Collon, 1982: no.72), also in worshipping scenes the gazelle was lying beside the throne of the principal god or between the feet of the standing gods (Ward,1910:no344; De Clercq,1888: plXII.no106; Collon,1986 III: no.231,232,490; Frankfort,1955: no.714)

\section{2-4 Oryx (Orix leucoryx) :}

is one of the ruminants. It is a powerful animal. the animals true home is central Arabia its rarely in Mesopotamia it is distinguished from the Antelope by the heavier build and pale hair with contrasting dark markings in the face and on the legs, and their long horns are almost straight and long tail (Van Buren 1936: p 48 ) (fig.20)

The oryx may be the Sumerian alim, which is translated kaptu, great, honorable. The Semitic word for alim, oryx, is ditanu (Ward.1910: p416) 
The Oryx seems to be represented only on seals or stamp-seals the animal can be seen on seals impression from Tepe Gaura (Tobler.1950: fig.166; Speiser 1935: pl LVI-8; pl. LVII-28) (fig. 21) .in seals from jmdet Naser it appears with Antelope (Goff. 1963: fig 392) and it appears like ibex and antelope in herds (Genouillac,1934: no.3; De Clercq.1885.no1; Woolley .1934 :no.304;Frankfort .1955:nos.204,378)(fig.22) or in front of shrine( Frankfort .1955:no26) sized by the eagle of Lagash (Ward .1910: nos. 58,66,67) ,or defended by a hero from lion's attack (Von der Osten 1934: nos.87,89; Woolley .1934: nos. 243,244 ) or as a part of conflict scene (Collon.1982:59,95,68,99,119; Boehmer: 1965nos .98,140,153,160,165,176,230; Frankfort .1955: no.670) As a fill motif (Ward.1910: no176) (fig.23)

\section{2-5 Goats: (attudu)}

The ancestors of the modern goat were potentially two species, Capra falconeri, and the Bezoar goat, Capra aegagrus, being the most cited candidate (Capra hircus aegagrus is still found in its wild form in the Zagros mountains of Iran and Iraq). (Roets 2018: p4)

Different kinds of capridae appear in Mesopotamian iconography, but some species represented only once or twice - till now-. the markhur goat which has horns coiled on its own axis is characterized by two copper heads from Farah. (Hilprecht ,1903:Abb 53) (fig .24)

The species, (capra falconeri) has horns that are coiled and stretch backward in the horizontal direction. (Woolley 1934:UR II pls.87-90)(fig.21)

but the goat of (capra girgentana) species believed to be found in kish it seems to be drawn with exaggerated long vertical horn and also in a fragment from khafajeh it must have been very common from early periods it can be seen clearly among other species in Mesopotamian art.(Van Buren ,1939:p 58)

The Goat is frequently seen on the stamps, cylinders and in bas-reliefs...etc It is extremely common to see a goat brought in the worshiper's arms for sacrifice.(Moorey\&Gurney.1978:nos22,37;Ward,1910:nos.104,136c,137,212,214 ,215,251,261,276,292,294,298, $301 \quad, \quad 302,307,377,380$; DeClercq .1888: nos.176,178;Boehmer1965 :nos.350,381,387,458,561,644; Munn-Rankin,1959: nos.7,14,18;Legrain,1936:no.536;Woolley,1934:URII,nos,93,189,353;Collon .1982:II.nos.144,159,163,169,198,219,223;Collon.1986:III.nos.345,354) (fig.25) in one case we have observed what appeared to be the head of a ram brought to the god (Ward 1910, fig. I233.) another case, in a cylinder in the Louvre (MNB 1324) which may represent the sacrifice of a bull. (Ward. 1910: p367) 
At the earliest period The goats are seen driven out of a fold, or enclosure, it appears also with its shepherd as a part of a complicated scene in the legend of Etana and the eagle (Boehmer1965: nos 693-698,701-706 ;Ward .1910: nos.391396, Moortgat, 1969:plF-6) (fig.26)

And also as a part of hunting scenes (Ward,1910:no 597; Woolley,1934: ,nos .8,4446,73,143,200,301;Wiseman.1962:I.pls.14d,14c,16b,16h,16i,16j,16g ，17a ,17e,18i,18f,21a,21b,21c,22a,23f,24a,24f;Collon.1982:pl.VII) (fig.27) .

\section{2-6 Deer:}

The species of deer known in Mesopotamia are. Red deer or stag with the branching horns of Europe (Cervus elaphus), fallow deer or buck (Dama Mesopotamica) and roe deer or roebuck (Cervus capreolus) with a squarely-shaped horns. in the written Akkadian texts deer have been identified as ajalu,najālu, and lulimu with no clue to which species of deer the terms belong in the visual art it is easy to identify which species of deer is illustrated (Albenda, 2008:p62)

\section{2-6-1The stag:}

Two plates with remarkable design from Samarra where the branching horns of the stags are very like trees. In the first one, the artist ties the two animals together by using the legs of one for the other, the second is incomplete but clearly show the branching horns of the stag (Goff.1963: p 5, fig 39; p 37, fig 200) (fig.29,30)

The magnificent group in copper of two stages gripped by a winged eagle from the temple at Tell al Ubaid (fig.31) the same theme of the eagle and the stag appears also on the silver Vase of Entemena (Moortagat,1969:pl.113; Hall,1930, p259; Ward ,1910: fig 56) (fig.32)

And from Ur a lyre (U12355) with a boat-shaped in the front the entire figure of a stag stands upright with his front hooves on copper Its antlers, are relatively small and not spread out, resembling a younger roe deer opposed to a mature stag (Woolley.1934:pl112, U. I2355; Chandler.2013: p27-28; De Schaunsee 2002: p3539,pls.6,17,18)(fig.33)

Two gold pendants with laying stags. We believed to be a diadem (Woolley 1934:pl140,141 U. I0948; Chandler .2013: p39-40.img .21; Zettler ,1998: p 92).(fig.34).

Also Copper Stag Rein Ring from Kish with a big branching horns (Müller-Karpe. 1985: fig 1; Watelin, 1934: p33) (fig.35)

At kish a bronze stag with a clay core and the object was cast from a mold. Front and fore feet stand upon a short round pin, which proves that the object has a pedestal. (Langdon, 1924:p 92. pl. XXVIII.)(fig36) 
At Nineveh the teeth, jaw, and horn of a stag back to Jemdet Nasr period were found (Van buren,1936: p22).

It is not usual to find the stag in contest scenes, but occasionally he appears in the more archaic monuments. (Ward ,1910: figs 147,149,151)

In general, stags do not play a prominent role in Early Dynastic seals, but appear more frequently at later times. When they do show up in ED times, the seals normally portray combat scenes in which lions or men maul or hunt the stags, or the stags are shown amidst plants or trees. or attacked by lions (Ward, 1910: nos. 141,141a, $149 \quad 151,191,369$,499; Delaporte .1923: nos.17,19,21, Langdon.1924:pl.21nos.1a,d,pl22,no2;Legrain.1951 :nos.129,137 138,150 ,170 ;Wiseman.1962:pls.5a,16e,16b,17h,17g,18c,18d,18e,18j,22d,23g,26d,27e;Frankfort .1939:pl.VIb;Buchanon1981:no.305 ;Eisen.1940: no.19) (fig.37)

In Assyrian times the stag was not usually represented. Just a few times from Nimrud, Assur and Nineveh. (Collon.2001:V,no.60)

\section{2-6-2-Fallow Deer:}

Smaller in size than the red deer can be distinguished by its palmated horns and sometimes by its spots on the back and body

from the royal cemetery of UR a gold fillet with the stamped decoration of men and animals show a deer (Woolley, 1934: UR II, pl39. U 8173)(fig.38)

Apart of inlaid gaming-board from the royal cemetery of UR with lion attacking deer (Woolley ,1934: UR II, pl 96-97) (fig.39)

An engraved shell plaque from a lyre in royal cemetery of UR with two fallow deer flanking a tree (Woolley,1934:pl 104 d) (fig.40)

the fallow deer also appear in cylinder seals in examples that seem to be a little different from stag the animal is depicted within its natural habitat or as usual in contest scenes or attacked by lions or part of the heroic scenes (Moortagt .1969 :pl.M3;Collon1987:nos.277,915,962; Woolley,1934:nos.51,57,59,63,66,67,117 ,120,121,166,170,171,212,216; Ward1910:no.579,1066,1090;Albenda.1978: fig .5) or in front of shrines as apart of temple herds (Ward.1910:no.494)

From the ninth-century B.C a fallow deer appears in one of the friezes of the black obelisk of Shalmansr III in scene three wild animals running through a forest two lions and a fallow deer (Moortagat.1969: pl.270; Albenda.2008: fig 3) (fig.41). In the northwest palace of Aššrnâsirpal II at Nimrud one of the apkallu guardians of the doorway carrying a spotted fallow deer (Layard.1853:pl 35; Albanda.2008: p65).(fig.42) 
in the upper register of a wall relief from Snherib's palace shows a spotted fallow deer lying dawn among reeds (Layard.1853: vol II: pl.12)(fig.43)

\section{2-6-3Roebuck:}

This species, although it was quite common in Mesopotamia, it was very rarely represented in art

\section{2-7 Bovinae}

The Bison (Bison bonasus), the Arne-Buffalo (bos bubalis) and the Aurochs (bos primigenius) were all represented in Mesopotamian art more than any other animal

\section{2-7-1 (Bos bonasus) (ditnu)}

This is the "bull" of the more archaic monuments. probably identified by the Sumerian term GUD4.ALIM and the Akkadian kusarikku.(1)

The Babylonian name for the bison was rimu. The archaic sign for alpu, ox, was $\ddot{\nabla}$ and that for rimu was $\frac{1}{\%}$, in which the three enclosed wedges are the sign for mountain, so that the meaning was the bull of the mountains, a proper definition of the rimu or bison. (Ward.1910: p414).

The wild bovine was portrayed in Mesopotamian art since pre-historic times in natural, mythological, and religious contexts. Depictions of this natural animal are found in the round, in relief, and in glyptic art.

A copper bull's head was found in the Sin Temple at Khafajeh in central similar to the other Early Dynastic bulls' heads (Van dijk .2011: p 45).

A number of bull's heads were discovered in the Royal Cemetery at Ur. These bulls' heads were attached to the sound boxes of harps and lyres. The sound of these instruments was compared to a bull's lowing, which was considered a beautiful sound (De Schaunsee 2002:76, pl 27, pl 28; Van dijk .2011: p 41-43). (fig.44)

Copper figure bull from the temple of Nin-hursag at al'Ubaid (De Schaunsee 2002:p120; Hall \& Woolley 1927: pl.XXVII, pp.84-86)(fig.45)

The bison figured on cylinder seals. it was often represented attacked by a lion and defended by hero or bull-man, the species can be identified easily by its short horns. The contest scenes on the early seals from the Uruk and Jemdet Nasr periods depicted domesticated animals being attacked by wild animals. Contest scenes from

1- Black \& Green. 1992: P49; Wiggermann.1992: P174-177. Kusarikku (GUD4-ALIM) is probably the original name for the extinct bison ("kusarikku," CAD 8:584). This term was used for the bull-man and also possibly for the human-headed bull (Wiggermann, "Mischwesen. R1A 8:242; Frankfort.1939:p161; Black\& Green.1992: p48-49). The Akkadian term alu (gu4.an.na=e-lu-u) refers to the bull as a mythological being and is a different creature ("alû B," CAD 1.1:377). Gane. 2012 
the late fourth millennium generally represented a lion attacking a bull from behind. Later this developed into a frontal attack (Collon. 2005: p27, Goff.1963: figs.260,261).

By the middle of the Early Dynastic Period contestants were shown vertically, with animals standing on their hind legs. This change allowed for the development of more compositions with the animals having more complicated postures (Collon.2005: p27) Figures such as the hero and the bull-man became more common during the Early Dynastic Period, and the animal combat of earlier times developed into a mythical contest (Woolley.1934: Ur II nos .172, 207 231 ,233,310,311,313;Delaport.1923:T.81,pl.8,fig.12,T.83,pl.4,fig.1,D.9,12,pl.49 , figs.9,11,A.56,57,pl.65,fig.9,12,A76,pl66,fig.16;VonderOsten,1934:nos.96,99,111,6 79;Moortgat,1969:pl.D-2,E1;Legrain.1951:nos.93,123,137,140,142,168

;Ward.1910:nos.114,116,123,139c,141,141b,141d,142,143,151,171,175,516

;Wiseman.1962:16-f,20-f) (fig.46)

The association between the bull and the Storm God is first attested during the Old Babylonian Period when forked lightning, which symbolizes the god, rested on the back of the bull. The bull could be either standing or recumbent. The bull also supported the Storm God himself. sometimes he is shown standing with one foot resting on the back of the bull. (Van dijk.2011: p160; Ward.1910: nos.455-470a; Collon.1986: III.nos. 95,245,247,248,251,279,442,246,446,447,449,454

,4 58,460,521; Legrain.1951: nos.468,470,473) (fig.47)

\section{2-7-2Buffalo (bos bubalus)}

This is the native water buffalo of the swamps of southern Babylonia, which appears on the cylinders of the time of the Akkadian. It is an almost hairless black animal of huge size, six feet high at the shoulders, and with large ridged or crinkled horns, which fall back over the shoulders. (Ward.1910: p414-415; Van Buren .1936:p74; Collon.1982 .nos.71,75,77 ,76,78,80,81,82 ,88,89,90,91,96 ,97,108,125,206;Woolley.1934:no178,183,185,228,236-40,248,309,316,317

,569;DeClercq.1888:nos.46,5052,54;VonderOsten.1934:nos.95,97,98,100;Delaport. 1920:p13.fig13,p18.figs6.8,p149.figs8,1315,p164.fig.7,p166.figs.10.15b.16;Delaport.1 923:pl67.figs 11;Genouillac.1934:fig.1;Wiseman.1962:no.34;Ward.1910:nos.135b,1 57,161,163,167,177,180,183,187;Boehmer.1965:Abb.15,29,124,137140,141,152,160-164,165-171,173,181,183,185,187,188,191,192,197 ,201,202,209,215,216,219,223,226,232,256,257;Legrain.1951:nos.182,183,18 6)(fig.48) 


\section{2-7-2The Aurochs (Bos primigenius)}

the Aurochs probably the ancestors of all modern cattle. And apparently domesticated in early time. they have long upright and bent horns it shows in purely agricultural scenes. The oxen attached to the plow are distinctly not the bison nor the buffalo, but, it doubtless originated in the aurochs, Bos primigenius, now extinct (Ward .1910: figs.369,371,372)

on seals aurochs seen in herds among other animals both wild and tamed

(Wiseman.1962:p.5,pl.5a;Frankfort.1939:pl.VIa-b;Boehmer.1965:Abb.76,296 ,358)

Cylinder seal from Uruk shows a man feeding cattle with branches (Buchanan .1981: no. 134), also seals showing a man driving a bull or bulls attacked by lions (Wiseman.1962:pl.15c,20c,21e,45;Von der Osten.1934: no.695; Woolley .1934 :pls.201,111; Goff.1963:p62,figs.247) (fig.49)

\section{3- Horned Mythological Creatures:}

\section{3-1 Bull-man:}

the bull-man was an anthropomorphic figure with th face and upper body of a man, and the lower body, ears, and horns of a bull.

The bull-man or bison-man was developed from bison which was represented at first naturalistically but later with a human face and short round horns .and that it represented the supreme of human and his control (Wiggermann .1992: p174; Van Dijk .2011: p68; Ward.1910: p427, nos. 176,177,180,181, Frankfort,1939: p61). He was first attested in Mesopotamia since the Early Dynastic Period, (Black \& Green.1992: p48; Collon. 2005: p197), he was common on cylinder seals. shown in profile with only one visible horn, he appears singly, in pairs (Black\&Green.1992: p48-49), and since original bison was roamed the hilly flanks of the Mesopotamian lowlands. And the mountains were his home and he associated with other fabulous beasts.by the Early Dynastic II period he was the protector of flocks and herds.in iconography (Frankfort,1939: p171)

In the Sumerian period, he is known as gud-alim, and in the Akkadian period as kusarikku (Wiggerman1992: p174).

Assyriologists of an older generation have identified the Bull-man with Enkidu, and though this identification is now generally abandoned (Frankfort, 1939: p 61)

In the Akkadian period, the bull-man is shown at the beginning as an enemy to the sun god (utu)Šamaš in Akkadian. then became associated with him he was the (sunirdUtu), "emblem of Utu", (Frankfort .1939: p161; Wiggermann 1992: p174; Van dijk.2018: no.6). during the Akkadian period, the bull-man's association with UTU is transformed into a master-servant relationship, so he becomes a protective figure at significant entrances. (Wiggermann, 1992: p226.) 
in the Old Babylonian period, the bull-man's close relationship to UTU is indicated by his logogram: GUD.DUMU.dUTU, "bison-son of Utu." (Wiggermann, 1992: p176).

Also during the Old Babylonian period and into the Kassite period, he continues as the attendant of the sun god (De Clercq,1888: 236; Von der Osten.1934: 149) carrying the standard of the god. At times he also bears the standard of the moon god, Sin (De Clercq.1888: 112 Frankfort.1939: p171). However, also during the Kassite period, the kusarikku (bull-man), is the enemy of Ninurta/Ningirsu, a storm god, who defeats him at sea. (Wiggerman, 1992: p177 n. 18). The bull-man remained a popular figure in art until the Achaemenid period the bull-man appear in contest scenes, whether depicted alone, in pairs, or threes as they struggle against wild animals or humans. Early Dynastic III period glyptic scenes portray the bull-man fighting Lahmu, the hero with curls. This contest became the most common theme of Akkadian period glyptic art .(Black\&Green.1992:p49;Ward.1910:nos.120,187a,187b;Collon.1982II:nos.12,22,2 4,25,28,33,72,76,77,83,86,87,93,94,105,251;Wiseman.1962:pl.14f,15d,17a,18a,18b ,18c,18j,19a,19b,19d,20h,20f,21a,21c,22a,22b,28d;Frankfort.1939:plXIIa,b;Woolle y.1934:nos.43,46,55,58,64,66,69,7375,146,147,151,157,166,168,169,170,172$175,182,183,185,225,229,230,232,235 ;$ Boehmer.1965,3-8,10,22 ,34-38,51$58,75,109-113,129$-147,156,157-171,178-188,197-202) (fig.50)

\section{3-2 human headed bull:}

Human-headed bulls are first appearing in the art of the Early Dynastic Period in Mesopotamia and continue to appear until the Achaemenid Period. They acted as protectors in Mesopotamia.

Their role as apotropaic figures can be traced back to the beginnings of civilization. This use will be traced from the Neolithic Period until the Persian Period to reveal developments in its use

The terms aladlammĩ, lamassu, šédu, apsusu have been used to designate those composite creatures of bulls with human heads and horns those protectors were originally associated with the Sun God Shamash ( Black ,2000:p10 ;Wiggerman ,1992:p95;CAD1/A.p287;Vandijk,p245-246; Black \&Green .p51; Reade 1979:p 41) The earliest representation of such composite bulls is from the Early Dynastic Period. alabaster Pouring vessel with relief now in the Museum of the University of Pennsylvania(B17087). (fig. 51). an arm-rest in the shape of a human-headed bull from Khafajeh (fig.52) The style of these pieces differs greatly, although the iconography of the creature is steady. The bull is lying down with a bearded human 
face and Two horns emerge from the top of the head. This general pose remains the same through the third and second millennia. (Van Dijk,2018: p245)

The Assyrian gateway guardians are the most famous examples of those protective beings, (fig.53) whose names were usually mentioned for protection in the building inscriptions of the kings like Tiglat-pileser III, Sergon II, Sennacherib, Esarhaddon (Reade 1979: p 41).(fig.53)

\section{3-3 horned viper:}

The horned viper (Cerastes cerastes), a mildly venomous snake has a pair of spikelike folds on its head. In art, the form of a snake with a pair of horns rising from the forehead appears as a magically protective creature on Kassite kudurrus (Seid1.1989: p155-156) and in Neo-Assyrian art as an element of seal designs and in the form of magically protective figurines. It has been identified as the creature called in Akkadian bašmu (Sumerian muš-šà-tùr). but by Assyrian times the figure was often a magically protective type. A variant horned snake with forelegs was apparently regarded as a different creature, although carrying in Akkadian the same name bašmu (Sumerian ušum). also known as ušumgallu (Sumerian ušumgal). (Black\&Green : p167;Gane 2012:p 199)

Bă̌mu was among the hybrids that were apparently slain by the warrior god Ningirsu in the Early Dynastic tale of the Slain Heroes. The bašmu is included among the eleven composite creatures that Tiamat created to fight against the younger gods (ba-aš-mu, Enuma Elish I:141). Reflecting high Mesopotamian respect for the potency of snakes, four out of Tiamat's eleven creatures are snakes or snake dragons bred in her fertile waters: mušmahh̆u (seven-headed dragon), ušumgallu (gigantic serpent), bašmu (serpent composite being), and mušmahhu,(furious snake; snake-dragon).

(Gane.2012:p202-3)

\section{3-4 snake-dragon}

The Akkadian mušhuššu literally (fearsome serpent) is one of the most popular of the Mesopotamian hybrid. It is found from the beginning of the Akkadian period to the Hellenistic periods. (Gane.2012: p.205)

The identified representations show a composite being with the front paws of a lion and hind paws like the talons of a bird of prey. With a long neck and the head of snake, a forked tongue, on the head two straight horns - in the older example it looks like a horned crown(fig.54) (Van Buren.1936:fig8; Wiggermann 1995: p 456; Boehmor,1965: nos.567-572; BM103381)

the mušhušš $u$ was associated with many deities, it was one of the four snakes or snake-dragons in the waters of Tiamat. then, it became linked with the chthonic 
deities of the earth, and later it was associated with the sea. It was initially also associated with the god Ninazu, "Lord Healer," lord of Eshnunna and ruler of the Netherworld during the Akkadian period. (Black \& Green, 1992:p166)

In this context, the dragon was the "angel of death, killing with his venom on the command of his master." (Wiggermann1989: p122.)

Standard Babylonian incantation states that Ninazu was the original of the mušhuššu (Wiggermann1989: p122.) In the Labbu myth, the "Raging One" is ravaging the land, so that both gods and man are terror-stricken. The name of the attacking creature, labbu, means "lion" in Akkadian; however, in the text the same creature is also referred to as a MUŠ.HUŠ, "Furious-Snake." The nation is derailed, everything is in chaos, and kingship is offered by the gods to anyone willing to risk his life to fight against the terrorizing labbu/mušhǔšsu. Tishpak (a snake god of uncertain origin) comes forward, stirs the clouds, creates a storm, and raises his seal. He hurls his seal down upon the composite being and kills him. The blood of the dragon flows for three years, three months, a day, and a night. (Wiggermann1989: p122.)

After the death of the horrendous hybrid, which was Ninazu's creature, labbu/mušhǔšsu becomes the attribute animal of Tishpak, the victor, when he takes over

In the Old Babylonian period, the snake-dragon Transferred to be Marduk's animal. Marduk and his son, Nabu, consistently employ the mušh̆ušs̆u as their divine mount and associated animal (Wiggermann, 1995: p 459 ) At the same time, Enlil also claims the mušhuššu as his mount. Meanwhile, Tišhpak, having lost the mušhuššu to Marduk, takes over the bašmu as his creature. (Wiggermann 1989: p121) Since the mušhušš $u$ goes to the god who gains higher status, it appears to be regarded as superior to the bašmu. This is based on the fact that the four-legged mušhuššu possesses greater capabilities, as implied by its more powerful physical morphology, than the two-legged bašmu.

In the Kassite period the kudurrus show the creatures and symbols, including examples of the mušhušš $u$. On these, the snake-dragon supports a stand that carries either Marduk's spade (marru) or Nabu's stylus. (fig.55)

(seidl.1968: Abb.4-40, Abb.7- 61, Abb.8-62, Abb.10-64, Abb.11-n74, Abb.12-75, Abb.13-79, Abb14-80, Abb16-84, Abb.22-103, Abb23-108)

Later, during the Ninth Dynasty of Babylon, stone monuments continue to display iconography similar to that of the earlier kudurrus. However, a cylinder dedicated to Marduk (in Vorderasiatisches Museum VA Bab 00 646) presents a magnificent 
representation of Marduk himself, standing beside his snake-dragon. ( Heuzey. 1906: p102; pl IV)

It also appeared on Old Babylonian terracotta, was articulated in the form of clay figurines in the first millennium, and was shown in a rare depiction of an Assyrian relief from Ashurbanipal' s palace at Nineveh (Ornan .2005: p114, fig151). The mušhuššu. Also guard Neo-Assyrian palaces, as in relief of Ashurbanipal from the North palace at Niniveh also seen in the glazed brick which NebuchadnezzarII decorated the gate of Ištar at Babylon repelling the evil and enemies. (Wiggermann,1995: $\mathrm{p}$ 460)

\section{3-5 The Horned Lion Griffin}

A Horned Lion Griffin, previously called a 'horned lion' is a composite animal whose body parts derive from four different animals. The creature has a lion's head with bull's horns, bird's wings sprouting from the foreleg joints, lion's forepaws, a bird's hind legs, and a scorpion's tail. (Watanabe .2002: p136; Gane,2012: p118; Braun-Holzinger. Löwendrache. RIA 7: p98.3c)

The horned lion enters the iconographic repertoire of Mesopotamia during the Akkadian period and continues to the Neo-Babylonian period. It is variously associated with the composite being Asakku (ASAG) and the Anzu bird (IMDUGUD), as well as the deities Adad (ISHKUR), Ashur, and Sin (NANNASUEN). (Gane. 2012: p121; Black \&Green .1992: p 121)

In the NA period the horned lion was split into two beings one with a feathered tail is called Anzu the enemy of Ninurta, (fig.56) the other one with scorpion's sting, graphically illustrates the attribution of this creature to Ashur, Sin, and Adad, each of which surmounts a lion dragon. (Wiggermann,1994: RlA 8:223)

It is represented on cylinder seals and in clay or stone reliefs. The creature is depicted surmounted by a male deity who chases after Anzu with a bow and arrow, or by a god holding either an ax or a mace. The Horned Lion Griffin always appears as an attribute of a god; it never occurs by itself. Although the representation of the Horned Lion Griffin is commonly found in iconography in the first millennium B.C., (Watanabe .2002: p.136)

\section{3-6 the goat-fish}

The goat-fish sacred hybrid of Ea a creature with the head and forelegs and horns of goat and body of fish represented from Ur III through to Seleucid times (Wiggermann, 1994: p257; Ornan,2005: p 125)

the goat-fish is known in the Akkadian as suhurmaš̂u (from Sumerian SUHUR.MA ̌́, which combines SUHUR [Akkadian purādu], "carp," with $M A \check{S}$, "goat"). Therefore, the designation literally means "carp-goat." particularly 
common on sixth- to fifth-century Babylonian seals as the sole element on the seal ( Wiggermann , 1994:p257 ; Ornan,2005:p 125; Black \& Green, 1992:p 93; CAD 15:351-352; "suhurmāšu,")

In iconography, the goat-fish can be placed next to the ram-headed staff of Enki like the kulullû, the suhurmaš̀ $\hat{u}$ is at home in the cosmic waters of the Apsu, the domain of Enki, the suhurmaš $\hat{u}$ goat-fish is associated with water, flowing vases, and Ea. and described as the "lofty, purification priest" of the Apsu. He is identified as one of twelve monstrous creatures who accompany Marduk. (Black\& Green,1992: p 93; Wiggermann ,1992: p184; see Collon,1986 :no52 ,73,92,145,272,273,274,345,402,460; Collon 1982: no.404) (fig.57)

In the Kassite period, goat-fish are portrayed on kudurru stones as guardians of boundaries.(Seidl,1968:p40.Abb9.nr.63,p46 Abb12,nr75)

from the library of Ashurbanipal at Nineveh. Here suhurmaš $\hat{u}$ with other creatures oppose evil and invite good, as evidenced by words to be inscribed on the wooden statues: și-i, "go out (evil)" and er-ba, "enter (good)" (Wiggermann, 1992: p141142) Texts assert that a goat-fish, like an exorcist, imitates Marduk by holding an e'ru, "cornel(-stick)," in his left hand. The stick is to strike the "evil one". (Wiggermann, 1992: p69)

However, no figurine of a suhurmašû has been found in which the creature actually has hands and holds such a weapon. (Wiggermann, 1992: p 84).

\section{3-7 Pazuzu:}

Nothing is more usual than to find various beings usually of demoniac character invested with horns like the horned demon Pazuzu Son of Hanpu, king of the evil winds (lilï)( wiggermann .1994:p375). He was a prominent demonic being during both the Neo-Assyrian and Neo-Babylonian periods. His complex character is both malicious and protective. Because he is simultaneously evil and good, he wields exceptional power over his sphere of influence. (Gane.2012: p127)

Pazuzu's demonic character is splendidly illustrated by his iconography which was a mixture of theomorphic and anthropomorphic elements that comprises his features. the most notable is the rectangular form of his head, capric horns, canine jaws with the teeth and tongue shown, and large, round eyes under thick eyebrows. Human beard, ears, round bulges on his head. A prolonged, small, canine body with protruding ribs, human or animal thighs and bird's talons, human shoulders and arms ending in the Claws of a predator, two bird's wings, a penis erectus ending in a snake's head,a tail of scorpion complete Pazuzu's demonic iconography. (fig .58)(Heeßel. 2011: p 384; Wiggermann .1994: p353; Green,1985. p76) emerges fully in the eighth century B.C. Pazuzu was a prominent demonic figure during both the NA and NB periods. Several different explanations have been put 
forward for his sudden, iconographically fully developed appearance in the first millennium B.C While there seems to be an iconographic connection to foreign god representations a possible Mesopotamian origin cannot be excluded (Heeßel. 2011: p 385)

pazuzu's nature and his use in magic define two component parts, never completely integrated. On the one hand pazuzu is a domestic spirit, a permanent guest in the houses of man, and on the other he is a wind demon, an untamed loner roaming mountains and desert (Wiggermann .1994: p353)

The earliest securely datable Pazuzu representations stem from the royal tombs in Nimrud. which can be dated to the end of the $8^{\text {th }}$ century B.C while the earliest reference to Pazuzu in the text is found in a letter dated to around 670 B.C. Most of the heads, amulets, and statuettes can be attributed to the $7^{\text {th }}$ and $6^{\text {th }}$ century, B.C and the latest were found in Seleucid contexts. (Heeßel, 2011: p359)

The identification of Pazuzu in iconography is based on NB figures inscribed with the incantation "I am Pazuzu." Texts that mention Pazuzu include incantations as well as letters and omens. No texts that mention Pazuzu date earlier than the 7th century BC.( Heeßel,2002: p30.)

Pazuzu has a special connection to the Mesopotamian demoness Lamaštu this much feared demoness who responsible for the death of infants and attacking pregnant women. Pazuzu sometimes depicted right beside her on amulets he was somehow away to expel her. ( for Pazuzu representations and Lamaštu see Heeß1.2002:nos1932)

\section{4-The horns of the god and king}

In literary texts gods have horns that can go back to the primeval ages, which was a reflection of older belief to the connection between the horns and the power they represent and the divine world. We can find clearly that the animal metaphors are used as a divine epithet to confirm the powerful nature of the god like a bull - ('iluSin bèl kar-ni), the god Sin'lord of the horn'(Langdon.1915: p191:li 7)

- the Moon god Nanna was described as (amar.bàn.da si.gur4.gur4.ra)

"fierce young bull with very thick horns"

-Bel cut off her (Tiamat's) horns (Bèl si. MEšs ša ukarrit) ( Ebeling, 1919: no.307 r 13)

-Ninurta's power is also expressed by the description of the wild bull. In the Sumerian myth 'an-gim dim-ma',Ninlil describes him as "the wild bull, with fierce horns raised" (am à huš il.[il]) (Cooper 1978,p 74 , Angim -110; Pfitzner.2019 : p159) 
- Ninlil,"the wild cow", gored my enemies with her strong horns" (Ninlil rhìmtu ... munakkip nakrēja ina qarnēša gasrāti) (Streck, 1916: II .no 78 ix 78)

- the storm god Iskur/Adad with the bull, the god is described in his epithet as "the horned wild bull" (am si.mu a.a ${ }^{d}$ iskur.ra: rìmu qarnu abi ${ }^{d}$ Adad)

(Watanabe.2002: p 97)

*(Nergal) năš SI.MEš eddèti ( Böllenrücher.1968 :no 50:3)

*(Nergal) am-ma-az-za-ba-Ši-qub-bé-en si-gal-zu bi-tu

You are standing like a wild bull; your great horn has smitten them (line 49) (Sjöberg.1973-74: p4)

describing the horns of the gods literally was easier than iconography. since the gods in Mesopotamia were conceived in human shape so they need to be distinguished from humans. by the sign of divinity that sign was the horned crown as a symbol of power, divinity, fertility. From the Jemdet Nasr period the horned crown first appeared and remained throughout ancient history. (Frankfort,1939: p22)

Such a headdress is worn by gods, sometimes by the deified king. However, the mortal who claimed divine honor was not allowed to be depicted with a horned crown and goddess robe at the same time (Boehmer.1972-1975: p431) (fig.59)

The upper register of the Warka Vase found at Uruk and dating to the Uruk Period, contains a depiction of Inanna with a horned headdress a symbol of her divinity is clearly visible just to the right of the break. The horn is short and thick. it is uncertain what kind of headdress this horn was attached to, but it may have been either a band or a low cap. This depiction is a unique example of the horned headdress at this early period. (fig.60) (van Dijk, 2011: p131)

The oldest evidence of horned crown can be found in the art of the early Dyn. III.A shell plaque shows a single god (Ninurta) confronting a seven -headed dragon in battle the god wears a headdress with horns (Westenholz,2004 :p191) (fig.61), some other crowns show additional plant elements in the middle and a further development sometimes offers a horn-crowned truncated cone in the middle of the headdress, which sometimes shows a face (Boehmer1972-1975: p431)

On Eannatum of Lagash's Stele of the Vultures, the gods are depicted wearing a crown that has horns. In the center of it. bull's face and vegetation elements as a symbol of the role of god's fertility (fig.62) Such headdress worn by the goddess Nisaba on a fragment of a stone vase, now housed in the Vorderasiatische Museum in Berlin VA 07248(fig.63). (van dijk .2011:p131-132) 
During the Akkadian period, the headdress is similar in appearance to the Early Dynastic horned cap. beside Other conical horned headdresses with five pairs of horns spreading outwards. many headdresses were used at the same time and sometimes occur together on the same artifact. A cylinder seal in the BM represents a worshipper and three gods approaching a seated goddess. The three gods wear the second, while the seated goddess wears the simpler horned crown (Boehmer,1965:no541)(fig.64). the most famous headdress that of the Akkadian king Naram-Sin. he wears the horned headdress usually reserved for deities The horned headdress appears as a helmet with two encircling horns. (Moortgat, 1969: fig 155-156; also cff. Boehmer :1965: fig 292; Van Buren,1946: fig 17)(fig.65) and There are still crowns with plant elements. the crown of the moon god is recognizable with the crescent moon lying on the tips of its horns The top of the headdress, turned to be around and filled more and more The high rank of certain gods is shown by a multitude of horns (McMahon ,2006: pl.157/2)(fig.66). The usual simple crown survives during the Akkadian period and for a long time, although it changes a little over time, but still popular in the 2nd millennium and can still be traced to the 1st millennium. (Collon 1982: figs.157,173,224,231, Boehmer 1965: figs.280; 283 ,287,297 -309; Van Buren,1946: fig 6,7,10,15)

By the Isin-Larsa Period the caps were domed with up to seven pairs of horns which curved inwards on the headdress rather than protruding out from it .and we still find the traditional cap

in the old Babylonian period, is also worth mentioning the emergence of horned Tiera with feathers worn by female deities such Ishtar, Nanna a

good example for it found on the kudurru of Meli-ši-hu we see here the goddess Nanna sitting on the throne wearing her feather crown (seidl. 1968: tafe:11a), and god like Marduk wears it also the architectural crown in the form of a temple façade.

In the Assyrian period the usual crown, conical crown, and rounded high caps with one or two horns are still there, and it is often crowned with a star from the time of Adadnirari III. And later with other symbols such as the moon as a crown for the moon god or the winged sun as the crown for the sun god. (Boehmer, 1972-1975: p431-2)

From the early $3^{\text {ed }}$ millennium B.C the horned crown was seen as a separate symbol, often standing on a pedestal, from the Kassite Period down to the Neo-Babylonian, and continued to be represented as a symbol of divinity. On Kassite kudurrus the symbol is named as that of the god Anu (An), but in Neo- Assyrian art it was apparently transferred to the god Assur. Sometimes, however, three crowns then 
represented Aššur, Anu (An), and Enlil, two such crowns symbolized the latter two, with very occasionally a third one standing for Ea (Enki) in place of his ram-headed staff. (see seidl ,1968 :p116-117;Nr.25,28,34 ,40,44,48,49 ,61,67,71 ,74,76,77,78,79,80,83, 84,97,98,100,106 )(fig.67,68)

\section{5-Semi-divine beings with horns:}

*The Apkallu: were seven mythical sages. the Sumerian expression AB.GAL refers to the priest or an exorcist. The Akkadian term gives the same meaning. (Wiggermann,1992: p76) the apkallu were not just mythical beings or humans but also gods. Ea, Gula, Enlil, Adad, Marduk, Nabu, and Gerra. the apkallu came originally from Eridu the city of Ea/Enki, (Dally,S, "Apkallu," IDD 1) and In the Babylonian Gilgamesh Epic, they built the walls of Uru. (Gan, 2012: p17)

the representations of the apkallu appear to be developed in the first millenniumBC. especially in glyptic art. the representations of apkallu were associated with the king in NB palaces especially that of Ashurnasirpal II.

The human-figured Apkallu is often shown wearing a horned crown with one, two, or three pairs of horns; he wears light sandals or is barefoot. (Dally, "Apkallu," IDD,3) (fig.69)

The human male apkallu is rarely associated with a particular deity and is seldom seen with other non-apkallu composite beings. He is Rather than grasping an $e^{\prime} r u$ stick, the ūmu-apkallu could hold a (banduddh) bucket. (Wiggermann, 1992: p74), Another beardless apkallu, maybe female. found in the Northwest Palace at Nimrud. her divinity indicated by her two-horned headdress. (Albend.1995: p68)

The number of horns shown on crowns of divinity may have been reduced according to some artistic considerations or space; they do not appear to distinguish different ranks of apkallu.

\section{6-The horn of the moon}

The concept horns of the moon were Sumerian the god Sin was the lord of Ur. The resemblance between the crescent of the moon, and the horns of the bull connected them. Therefore, the bull, the crescent moon, and the Moon God became associated with each other. the Sumerian Moon God was known as Nanna. In Akkadian, he was called Sin. A hymn to Sin begins, "Proud bull calf with thick horns This relationship is highlighted in other texts which explicitly associate the horns and the light of the Moon God, such as line 13 of a hymn to Sin for Ibbi-Sen (Ibbi-Sene) which describes "with shining horns, the light of heaven, youthful Sen".

(Van dijk ,2011: p 6)

the connection between the bull and the moon at an early period a represented on Early Dynastic white stone plaque found in the Inanna Temple at Nippur, a crescent 
is found just above the depiction of the bull. also, two bulls' heads from a copper frieze that decorated the Early Dynastic Temple of Ninhursag at Ubaid (BM 118015) show a crescent on their foreheads, which identifies them with the moon, and the Moon God (Hall,1930: pl.VII-2)(fig.70)

the Babylonian and Assyrians used the concept of the moon horns in their astrological omens it was all about the extent, intensity, and color of the horns and for all about the horns of the moon (see. Thompson. the reports of the magicians and astrologers of Nineveh and Babylonian 1900, p.xxxvi)

\section{7-the Horn As amuletic medication}

The bull's Horns were often used as some kind of amuletic medication they mentioned three times .in one text, various materials are poured into it and it placed in the sick man's left hand while a torch is put in his right.in another text seven fragments of bread are mixed with water from a well, river, and grave and then poured into the horn. other meals and bits of bread are added to the mixture. incantations are pronounced; and the contents of the horn poured out before the man. (Goff.1956: p19)

Again a bull's horn is filled with water from a grave; meal and bread are added to it; and the contents are poured into a hole which had been made towards the west. A gazelle's horn is mentioned once to put the image of the person on it and bury it under a thorn bush. (Goff.1956: p19)

\section{8- the horns of the ziggurat:}

Many literary and artistic sources refer to the existence of the so-called temple horns, and whether it means here a decorative element added to the building or that it is part of the buildings like a tower, it is clear that it was a symbol of the power of the temple and its god.

-Kramer describing the temple of Nippur (the kiur of the Ekur of Nippur, raises its shining horns over Sumer "like a wild ox "Kramer,1969: p6"

-The Babylonian epic of creation, Enuma eliš VI.66

Šuršiš Ešarra inatțala qar-na-a-šú Marduk "regarda les cornes de l'Esagil" (Labat,1935: p151; CAD. Q vol.16. p139)

- On Cylinder A of Gudea boasts of having raised the of the temple of Ningirsu (Thureau-Dangin. 1907 p113)

And the well-known relief from the room I of Aššrbanipal's palace at Nineveh shows a three-tiered structure topped by a small building, the upper portion decorated with two pairs of bull's horn(fig.71), and on door H slab2 of Sargon's palace at Dur-Sharrukin there is Iranian fortress at Kišesim besieged by Sargon II 
during his sixth campaign The fortress topped by three pairs of stag horns (potts,1990 :p33-34)(fig.72)

Finally, Aššrurbanipal says in pride (ukappira si.MEš-ša pitiq erî namri) that he destroyed the Ziggurat of Susa and broke off its horns of shining bronze (potts .2016: p279; CAD .q p139)

This confirmation of the existence of horns for the ziggurats may indicate either that they were placed on top of these temples for protection or to show strength and sanctity, or that what was meant was the four raised sides of the temple.

\section{9- The horn as a Musical instrument:}

Horn was a musical instrument (wind instrument) its sound is generated by blowing the air in the Lips of the horn. The sound tube is conical and more or less curved. the horn may have been used very early, perhaps just for signaling but not for music since it has only one or two tones that could be produced due to the short and wide tube. (Stauder. Horn: p469)

The horns were sounded in Ancient Sumer of the third millennium as a call to mobilize the army, meet in the assembly, and as a prelude to public announcements. The earliest attested use goes back to the Early Dynastic period Sumer of the midthird millennium BCE, where the Sumerian compound verb, (si gì - ra) "to blow the horn," occurs six times in literary text from Tell Abu-Salabikh, and in a parallel from Fara (Ancient Šuruppak). (Biggs,1966: p81 note 60 f.; Biggs.1974: p. 37).

The Pictorial representations of the horn are quite rare About contemporary to these first textual examples is a steatite vase from the Early Dynastic period Adab (Bismaya) where one can see a small quartet of musicians who play the harp, lyre, drums, and what appears to be a bull's horn (Wilson.2012:pl.55)(fig.73)

By the end of the third millennium, further textual evidence for blowing the bull's horn emerges in administrative text 2000 B.C describing the sounding of a horn in the streets to announce the loss of cylinder seal by a merchant of the city of Nippur:

nimgir.e sila.sila.a si gù ba.ni.in.ra

the bailiff blew the horn in the streets ...

In the Sumerian Gilgamesh tale Gilgamesh and Huwawa, Gilgamesh himself blows the horn (si gù ba.ni.in.ra) to call the troops of Uruk to arms for his campaign to the Cedar Forest against the giant Huwawa. .(Horowitz. 2012: p.2)

Heralds (nimgir) are said to blow horns (si gù um.mi.in.ra) for a similar purpose in both The Hendursaga-Hymn, and in Lugalbanda in The Mountain Cave 24 (si gù ba.ni.ra).also in The Death of Gilgamesh, the blowing of the horn (si gù ba.[n]i.ra) is used to gather the dam workers to erect the mausoleum of Gilgamesh. The 
Sumerian horn found its place in the temple as part of the ritual. Also a wild bull's horn (si am.ma) is listed among a group of musical instruments in the Kesh Temple Hymn and one finds an ibex horn as a musical instrument in a ceremony in a hymn of Gudea of Lagash to the goddess Nanše

(Gudea, the governor of Lagash placed the Lyre, Cow of Abundance, among the drums, placed the sacred harp beside it. While the sacred song, the harmonious song, is performed before her (the goddess)) small copper ringers praise the temple, the chief musician plays the ibex horn before her. In this last example, the ritual context of the chief musician playing the ibex horn, rather than a bull's horn. (Horowitz. 2012: p.3)

A simple slightly curved horn appears on a plate from the palace in Karkemish (Woolley,1921: II, pl.18b)(fig.74)

\section{Conclusion:}

the horn is traditionally a symbol of power in the ancient near east. Egypt, Mesopotamia, Syria, Iran. such belief back to primitive observations to the fertility and power of the horned animals and their ability to defend itself such observations turned into admiration and translated into glyptic art.

Over time, human has been associated with these animals ideologically, deriving some of their ability and appearance

so the gods retained the horns of the animal (especially Bison), the horns were a symbol of their dominance and divinity horns are the gods "differentia specifica" which explains why Great gods like Anu, Enlil, Marduk, and Sin, and sometimes even Ishtar wore rounded caps with horns as a symbol of their powers and divinities.

also, the horn became an integral part of mythical composite beings such creatures whether of an angelic or demonic nature like kusarikku; bašmu, the lion-dragon ..etc. Demons also have horns like pazuzu, it connects them with their primitive wild animal life

One of The most popular beliefs about the properties of horn extends to the sounds made by horned instruments, which have been used for Centuries cause of their ability to ward off evil spirits, ghosts. 


\section{References:}

- Albenda. P. 1978: Of Gods, Men and Monsters on Assyrian Seals. The Biblical Archaeologist, Vol. 41, No. 1 (Mar)

- 1995: the beardless winged genies from the northwest palace at Nimrud. N Y,SAAB Xll

- $\quad$ 2008: Assyrian Royal Hunts: Antlered and Horned Animals from Distant Lands Bulletin of the American Schools of Oriental Research No. 349 (Feb.)

- Amiet, P. 1961 : La Glyptique Mésopotamienne Archaïque.Paris

-Amiet, p. 1980.: la glyptique mésopotamienne archaïque. Paris Archiv für Orientforschung 11. Bd. (1936-1937)

-Barrelet, M. 1968: Figurines et reliefs en terrecuite de la Mesopotamie antique, Paris -Biggs.R.D 1966:The Abū Șalābīkh Tablets.A Preliminary Survey JCS Vol. 20, No. 2

- 1967: Āš.ZI.GA: Ancient Mesopotamian Potency Incantations Thompson. R.C,1923Assyrian Medical texts.

- $\quad$ 1974, Inscriptions from Tell Abu Salabikh. Oip 99

- Black J. A.\&Green. A. 1992: Gods, Demons and Symbols of Ancient Mesopotamia (Austin: University of Texas Press)

- Black. J \& George.A..2000: A Concise Dictionary of Akkadian

-Boehmer.M.R.1965 Die Entwicklung der Glyptik während der Akkad-zeit

- $\quad$ 1972-1975: Hörnerkrone RIA 4/431-434

-Böllenrücher, J. 1968: Gebete und Hymnen an Nergal - Leipziger Semitistische Studien Band I, Heft 6 Leipzig, no 50:3

-Braun-Holzinger.E.A. Löwendrache. 1987-1990 RIA 7

-Buchanan ,1981: Early Near Eastern Seals in the Yale Babylonian Collection, New Haven, Yale University Press.

- Braun-Holzinger\& Andrea.E .2013: Frühe Götterdarstellungen in Mesopotamien.

University of Zurich

- Campbell.T.R. 1904: Cuneiform texts from Babylonian tablets, \&c., in the British Museum. Part XIX

-Chandler. P. 2013: Stags in the Sumerian Royal Tombs and their Anatolian Connections University of Colorado Boulder

- Civil, M.1978: 'Enlil and Namzitarra',AfO 25.

- $\quad$ 2010.the lexical texts in the schøyen collection. Cornell university studies in Assyriology and sumerology 12

-Collins. A.2002: history of the animal world in the ancient near east (Root,animals in the art of ancient Iran) Leiden

-Collon.D 1982: Catalogue of the Western Asiatic Seals in the British Museum: Cylinder Seals II: Akkadian, Post Akkadian, Ur III Periods. BMP, London 
- $\quad$ 1986: Catalogue of the Western Asiatic Seals in the British Museum: Cylinder Seals III: Isin-Larsa and Old Babylonian Periods

- 2005: First Impressions; Cylinder Seals in the Ancient Near East. London: British Museum Press

-Cooper, J.S 1978: the return of Ninurta to Nippur: an-gim dim-ma AnOr 52

-Dalley,S. 1972.Seals from the Hutchinson Collection Iraq Vol. 34, No. 2

-DeClercq.L1885-1888: Collection De Clercq: Catalogue methodique -raisonne, Antiquites assyriennes I: Cylindres orientaux

-Delaporte, L,1920/1923 : Catalogue des cylindres cachets et pierres gravées de style orienté by Musée du Louver II.

-Delougaz.P.1952: Pottery from the Diyala region

-Draffkorn.K \&Gordon.A. 1960/ 1 The Fauna of Ancient Mesopotamia. Edmund I Part B

-De Schauensee, M. 2002: Two Lyres from Ur. Philadelphia: University of Pennsylvania Museum of Archaeology and Anthropology.

- Ebeling, E. 1919: Keilschrifttexte aus Assur religiösen Inhalts, Zweiter Band (Hefts Funftes-Neuntes). ETANA.

- Eisen, A.1940 Ancient Oriental Cylinder and Other Seals with a Description of the Collection of Mrs. William H. Moore, OIP, 47 (Chicago , University of Chicago Press, 1940).

- Frankfort .H 1943: More sculpture from the Diyala region OIP 60

- $\quad$ 1955: Start field cylinder seals from Diyala region OIP 72

- $\quad$ 1939: cylinder seals, London

- $\quad$ 1935: Oriental Institute Discoveries in Iraq 1933/34 ( $4^{\text {th }}$ preliminary report)

- Gane .C.E. 2012:Composite Beings in Neo-Babylonian Art, Berkeley

-Genouillac.1934: Fouilles de Telloh. Tomes I-II

-Goff B. L. 1963: Symbols of prehistoric Mesopotamia. Yale

- $\quad$ 1956: The Rôle of Amulets in Mesopotamian Ritual Texts

Journal of the Warburg and Courtauld Institutes Vol. 19, No. 1/2.

- Gesche, P. D. (2000). Schulunterricht in Babylonien im ersten Jahrtausend v. Chr. (Vol. 275)

- Green,A. 1985: “A Note on the 'Scorpion-Man' and Pazuzu,” Iraq 47

- Green.A. 1994 :"Mischwesen. B,” Reallexikon der Assyriologie (RIA) 8.

Güterbock H. G. ,. Weidner E. F \& T. G. Pinches 1934 Keilschrifttexte nach Kopien von

T. G. Pinches. Aus dem Nachlass veröffentlicht und bearbeitet. AfO 13 (Fortsetzung)

-Hall \& Woolley 1927: Al-'Ubaid. A report on the work carried out at al-'Ubaid for the B.M in 1919 and for the joint expedition in 1923-4

-Hall.H.R.1930: A season's work at UR al-'Ubaid, Abu Shahrain (Eridu).london

Langdon .S .1924: Expedition to Mesopotamia Paris 1

-Haller.A1954: Die Gräber und Grüfte von Assur. Wissenschaftliche Veröffentlich- ungen der Deutschen Orient-Gesellschaft 65. Berlin 
The horns: symbol of power

An iconographical study in Mesopotamian Art

-Hansen, D.P.1998: Art of the Royal Tombs of Ur: A Brief Interpretation, in Zettler,R.L. and Horne, L. (eds.), Treasures from the Royal Tombs of Ur, University of Pennsylvania Museum, Philadelphia.

- Harper. R .F .1904:The Code of Hammurabi King of Babylon about 2250 B.C., by (Chicago )

-Heeßel.N.P.2002: PAZUZU Arcäologische Und Phlologische Studien ZU Einem Altorientalischen Dämon. Ancient Magic and Divination IV

- Heeßel.N.P 2011:Evil against evil. The Demon Pazuzu 2011, in: L. Verderame (ed.),Demoni Mesopotamici, Studi e Materiali di Storia delle Religioni 77/2, Rome

-Heuzey.L.1906: les deux dragons sacrés de babylone et leur prototype chaldéen Revue d'Assyriologie et d'Archéologie Orientale Vol. 6, No. 3

-Hilprecht . H.V,1903:Bel-Tempel zu Nippur .Leipzing

- $\quad$.1906: Mathematical, metrological and chronological tablets from the Temple library of Nippur. BE 20/1 Philadelphia

- Horowitz.W 2012: The Shofar and The Ancient Near East https://biblelandsreview.files.wordpress.com/2014/01/horowitz-bler-2012-s3.pdf

-Kienast, B, 1978, Die altbabylonischen Briefe und Urkunden aus Kisurra

Freiburger Altorientalische Studien Bd 2

- King. L.W 1912: Babylonian boundary-stones and memorial-tablets in the B. M, London

- Knudtzon J. A. 1978: El-Amarna tablets, 359-379: Die El-Amarna-Tafeln (Alter Orient und Altes Testament)

-Köcher.F,(BMA) 1971: Die babylonisch-assyrische Medizin in Texten und untersuchungen

- 1957 Ein Inventartext aus Kār-Tukulti-NinurtaArchiv für Orientforschung 18. Bd.

-Kramer S.N.1969: Sumerian Similes: A Panoramic View of Some of Man's Oldest Literary Images JAOS Vol. 89, No. 1

-Labat, R.1935: le poème Babylonien de la creation

- Lambert,W. G. 1966: Ancient near Eastern Seals in Birmingham Collections Iraq Vol. 28 , No. 1

- Landsberger, Benno 1960: the Fauna of ancient Mesopotamia MSL 08/1E

- Landsberger B. \&Civil M.1967: hubullu. Tablet XV and Related Texts. MSL9

-Langdon. S.1915 a fragment of a series of ritualistic prayers to astral deities in the ceremonies of divination Revue d'Assyriologie et d'archéologie orientale Vol. 12, No. 4

- Layard. A. H. 1853: The monuments of Nineveh, from drawings made on the spot, London, John Murray,

- Legrain L. 1936 :Ur Excavations Volume III Archaic Seal-Impressions

- $\quad$ 1951:UR Vol X Seal Cylinders.

-Macculloch.J.A 1914: Horns. Encyclopedia of Religion and Ethics Vol.6. 
-Mackay. E .1929: A Sumerian palace and the 'A"Cemetery at Kish, Mesopotamia "kish Part II Chicago

- Mark.W. 2008: Education in the Earliest Schools.

-Matouš, Lubor,1933 Die lexikalischen Tafelserien der Babylonier und Assyrer in den Berliner Museen / Staatliche Museen zu Berlin. Vorderasiatische Abteilung.Bd1

- McMahon.A.2006: the early Dynastic to Akkadian Transition -Nippur V. Chicago

- Meek T. J. 1944: Ancient Oriental Seals in the Redpath Library Bulletin of the American Schools of Oriental Research No. 93 (Feb)

-Moorey P. R. S. and. Gurney O. R.1973: Ancient near Eastern Seals at Charterhouse Iraq Vol. 35, No. 1 (Spring, 1973), pp. 71-81 (13 pages)

-Moorey P. \& Gurney O. 1978. Ancient near Eastern Cylinder Seals Acquired by the Ashmolean Museum, Oxford 1963-1973 Iraq.Vol. 40, No. 1 (Spring)

-Moorey, P.R. 1979 "Unpublished Early Dynastic Sealing from Ur in the British Museum.” Iraq 41

- Moortgat,A. 1969: The Art of Ancient Mesopotamia, London - NY, -Müller-Karpe. M. 1985: Antlers of the Stag Rein Ring from Kish J N E S Vol.44 , No.1 (Jan)

-Munn-Rankin J. M. 1959: Ancient near Eastern Seals in the Fitzwilliam Museum, Cambridge Iraq Vol. 21, No. 1 (Spring)

-Nils Ritter: human-headed winged bull (aladlammu)

HTTPS://WWW.ACADEMIA.EDU/13578532/HUMAN

headed_winged_bull_aladlammu_IDD-2010 cited 6/8/2021: 1:53

-Opificius, R. 1961: Das altbabylonische Terrakottarelief, Berlin

-Ornan, T. 2005. The triumph of the symbol: pictorial representation of deities in Mesopotamia and the Biblical image ban. Orbis Biblicus et Orientalis 213.

-Parrot.A.1958 Mission archeologique de Mari, Les palais peintures murales, Paris.

-Pfitzner.J ,2019:Holy Cow! On Cattle Metaphors in Sumerian Literary Texts

-Potts .D.T. 1990 notes on some horned buildings in Iran, Mesopotamia and Arabia

Revue d'Assyriologie et d'archéologie orientale Vol. 84, No. 1

- 2016: The Archaeology of Elam: Formation and Transformation of an Ancient

Iranian

-Reade 1979: Assyrian Architectural decoration: Techniques and subject-matter BagM 10

-Reade J. E.1980: The Rassam Obelis Iraq Vol. 42, No. 1 British Institute for the Study of Iraq

-Roets.M. 2018: Goats in the Ancient Near East and Their Relationship with the Mythology, Fairytale and Folklore of These Cultures

-Seidl.U.1968: Die Babylonischen Kudurru -Reliefs (Berlin: Gebr. Mann,

-Sjöberg.W. 1973-74 "Miscellaneous Sumerian hymns" Zeitscrift fur Assyriologie 63

-Spar, Ira \& Lambert, Wilfred G. 2005 Cuneiform Texts in the Metropolitan museum of art Volume II: Literary and Scholastic Texts of the First Millennium B.C II 
The horns: symbol of power

An iconographical study in Mesopotamian Art

-Speiser E. A. 1935:Excavations at Tepe Gawra VOL I

-Stauder.W.1972-1975: Horn, RIA. IV

-Streck, M. 1916:Assurbanibal und die letzten assyrischen Konige bis zum Untergang Ninivehs, II VAB.7. Leipzig.

-Thompson, R. C,1904, Cuneiform Texts from Babylonian Tablets in the British Museum vol 19.

-Thureau-Dangin.F.1907:Die sumerische und akkadische Kōnigsinschrif-ten Leipzig

-Tobler.A.1950 :Excavations at tepe Gawra vol II. university of Pennsylvania press,

-Van Buren,.E.D 1930: Clay Figurines of Babylonia and Assyria. Yale Oriental Series, Researches XVI (YOSR 16), New Haven, Yale University Press,

-Van Buren E. D1936, Mesopotamian Fauna in the Light of the Monuments. Archaeological Remarks upon Landsberger's, Fauna des alten Mesopotamien AfO 11

-Van Buren. E. D. 1939, The fauna of ancient Mesopotamia as represented in art. Analecta Orientalia 18. Pib, Rome,

-Van Buren E. D.1946 The Dragon in Ancient Mesopotamia Orientalia Vol. 15.

- Van Der Meer P. E. 1939 Tablets of the HAR-ra = hubullu Series in the Ashmolean Museum Iraq Vol. 6/2

-Van dijk, R.M.2011 The motif of the bull in the ancient near east, an iconographic study, S A

-Van Dijk. R. M. 2018: Mesopotamian Gods and the Bull. Sociedades Precapitalistas, vol. 8, no.1, 30 .

https://www.sociedadesprecapitalistas.fahce.unlp.edu.ar/article/view/SPe030/10232 cited. Date:2/8/2021 2:56 AM

-Von der Osten, H.H.1934: Ancient Oriental Seals in the Collection of $\mathrm{Mr}$. Edward T. Newell (The Oriental Institute of the University of Chicago . OIP.22.

1936: Ancient oriental seals in the collection of Mrs Baldwin Brett the Oriental Institute of the University of Chicago OIP37

- Virolleaud,c L.1909: Astrologie chaldéenne,,supp 2

-Watanabe C. E .2002 Animal Symbolism in Mesopotamia (A Contextual Approach) WOO, Band 1

- 2015: the symbolic role of animals in babylon: a contextual approach to the lion, the bull and the mušuššu Iraq -Volume 77-Issue 1- Dec.

- Watanabe .k 1993 Neuassyrische Siegellegenden .Orient 29

-Watelin, L. Ch. 1934: Excavations at Kish vol. IV Paris

- Westenholz, J.G 2004. Hybrid Creatures in the Ancient Near East: Their Character and Role. In Goodnick Westenholz, J. (ed.). Dragons, Monsters and Fabulous Beasts, 13-16. Jerusalem: Bible Lands Museum.

- Wiggermann, F.A. 1989 "Tišpak, His Seal, and the Dragon Mušhuš̌šu," in to the Euphrates and Beyond: Archaeological Studies in Honour of Maurits N. Van Loon. 
- $\quad$ 1992. Mesopotamian Protective Spirits. The Ritual texts.CM 1.

- $\quad$ 1994: Mischwesen B, RlA 8.

- $\quad$ 1995, mušhuššù RlA $8 / p .455-462$

- 2003-2005 Pazuzu, RlA 10/P.372-381

- Wilson.K.L 2012 Bismaya recovering the lost city of Adab OIP 138

-Wiseman 1959 / Cylinder Seals of Western Asia, Batchworth Press, London

Cylinder Seals I: Uruk - Early Dynastic Periods British Museum, London,

-Woolley. C. L. 1921: Carchemish Report on the excavations at Jerablus on behalf of The British Museum.

- $\quad$ 1962: The Neo-Babylonian and Persian periods, London

- $\quad$ I934: The royal Cemetery UR excavations volume 
The horns: symbol of power

\section{An iconographical study in Mesopotamian Art}
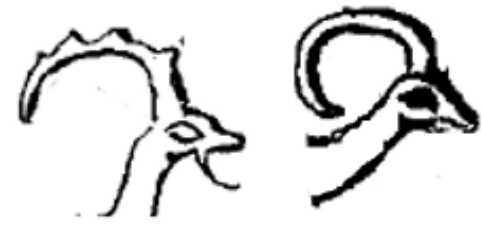

The Ibex - Legrain 1936

(fig 1)

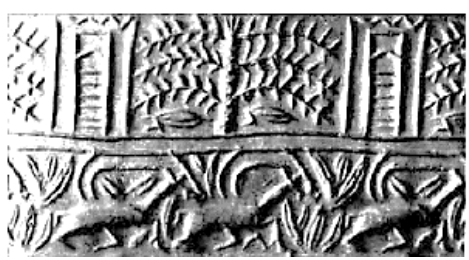

Fig4 Eisen1940 no27

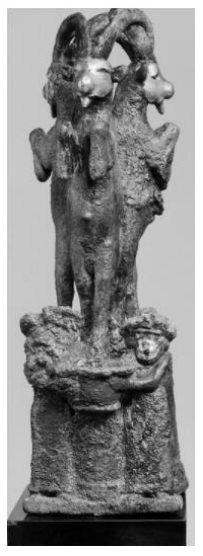

(fig.6)Louvre A015705.

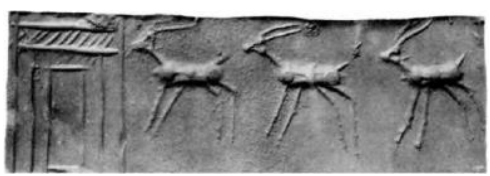

Von der osten1943,no24 Buchanan,1981,no168 De Clercq, 1888:no2

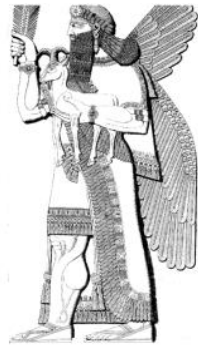

(fig. 9) Layard .1853 :pl35

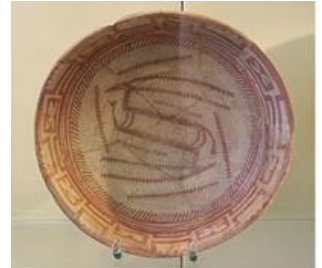

AV13408

(fig2)

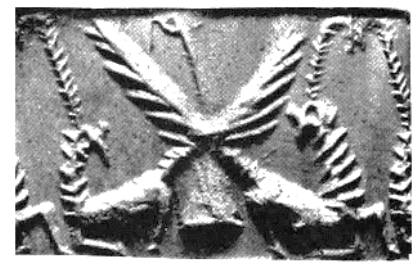

fig5 Legrein.1951:URX,nos111,114,

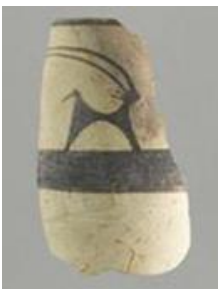

AO 15311

( fig3)

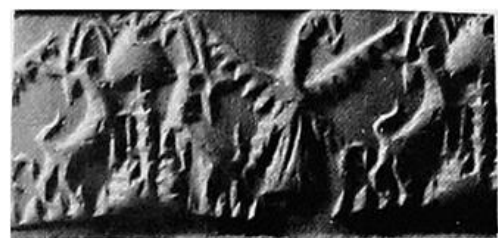

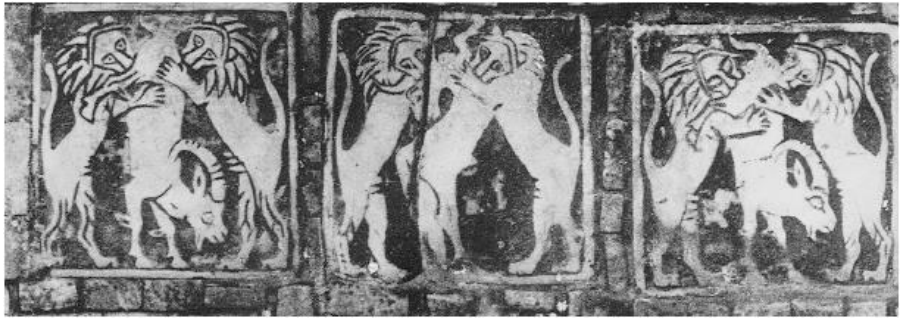

(fig7) Woolley, 1934 pl 97
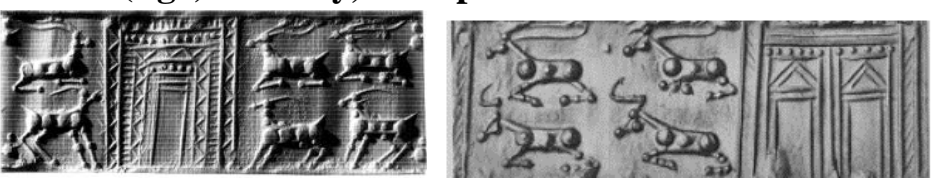

(Fig .8)
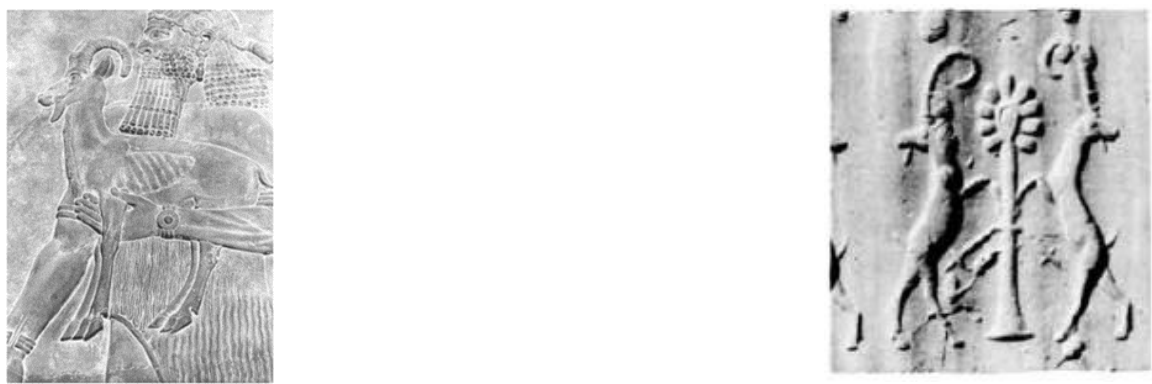

(fig 10) Eisen,1940:nos 98,99 

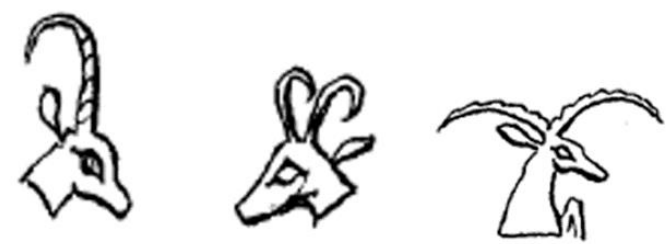

(fig 11) Antelope Lagrain 1936

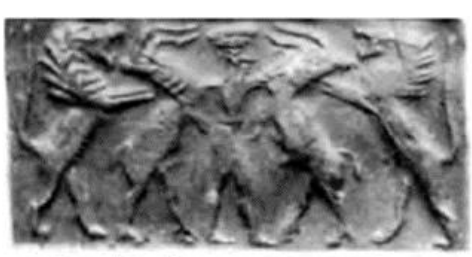

90

Von der osten 1934 :no90

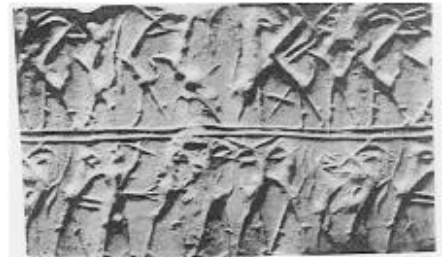

7r. U. 11938

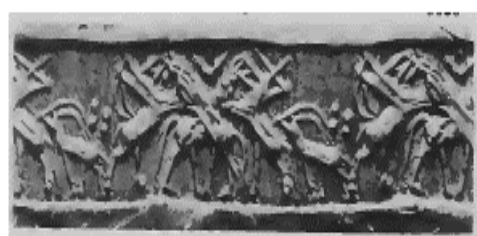

16

\section{$2312 \mathrm{~A}$}

Woolley.1934:no71

(Fig 12)

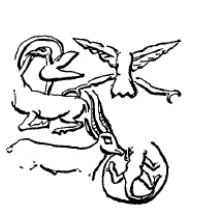

212

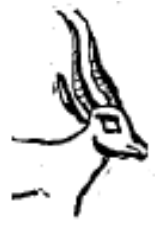

(fig13)

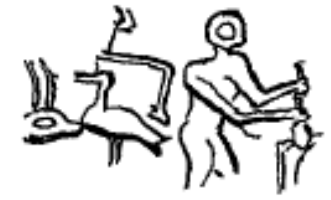

246

Mackay.1929

\section{Gazelle Legrain 1936}

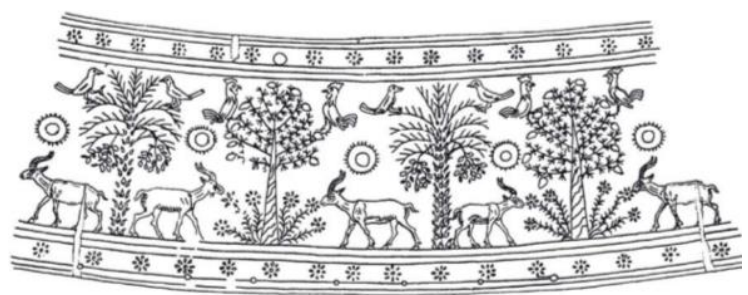

(fig .15) Haller 1954 abb 161 p135

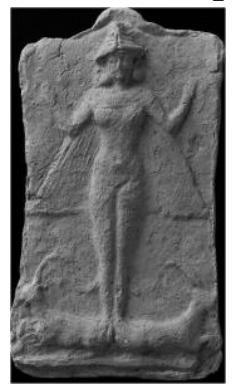

(fig17) Van Buren, 1930, no. 458 
The horns: symbol of power An iconographical study in Mesopotamian Art

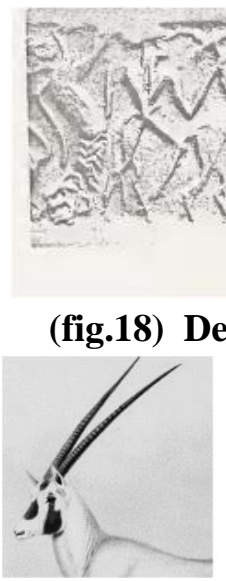

(fig 20) Oryx

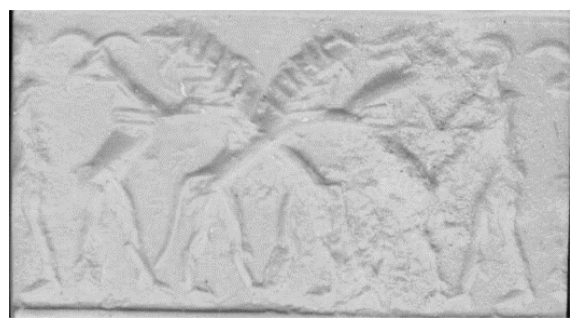

(fig19) collon,1982 : no55

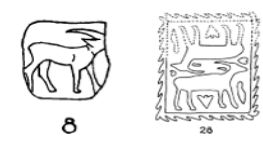

Speiser .1935:8,26

Tobler.1950 :no166

(fig.21)

(fig.22)

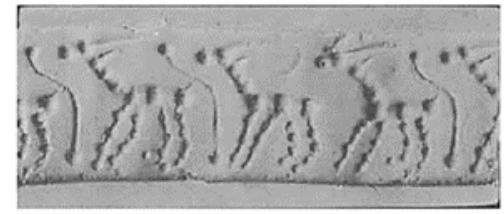

Genouillac.1934 :pl69.no3

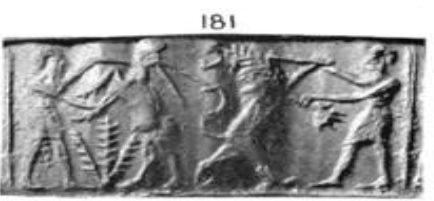

Legrein 1951:no181

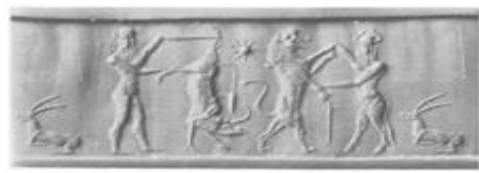

Frankfort, 1935: fig 1

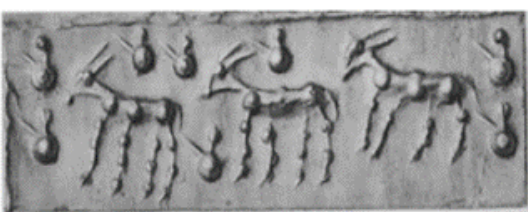

DeClercq.L1885:pl. 1.no1

(Fig.23)

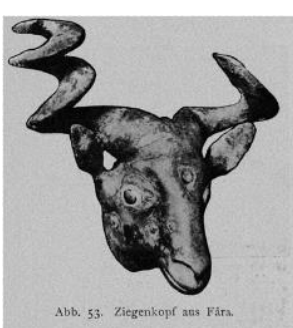

(fig.24) Hilprecht . H.V,1903:Abb 53

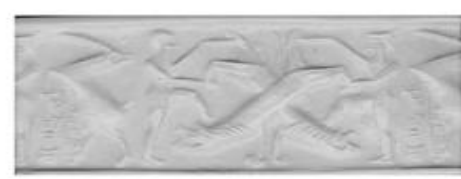

Collon.1982: no.119
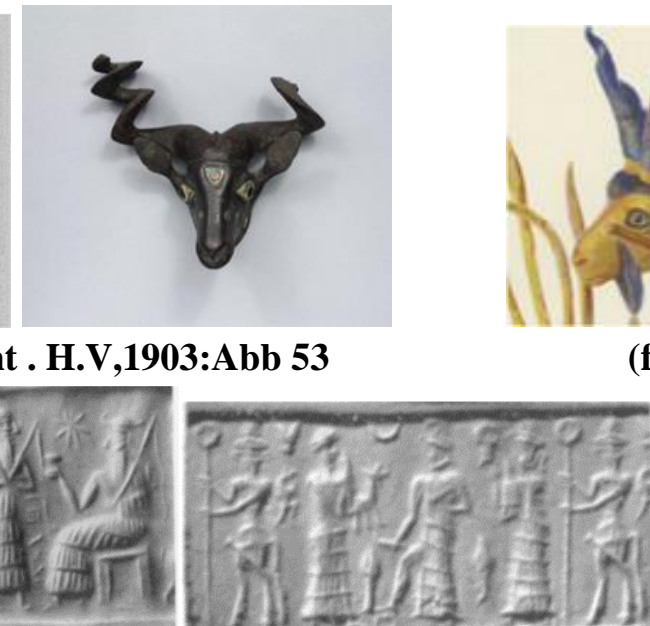

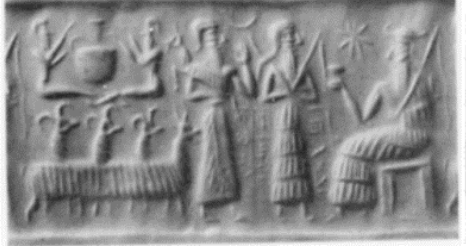

Moorey\&Gurney.1978:no22

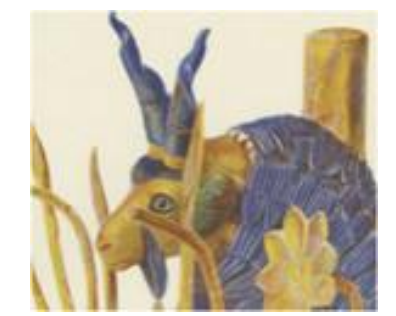

(fig.25)Woolley 1934

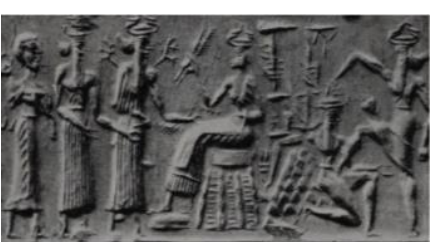

Boehmer1965 :no. 350

(fig.26) 


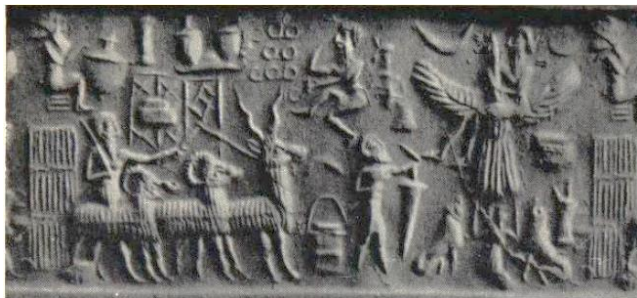

Moortgat, 1969 plF-6

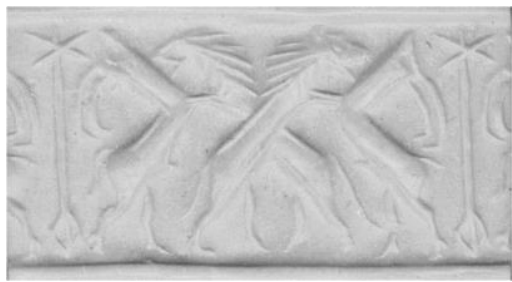

Wiseman.1962:no17e

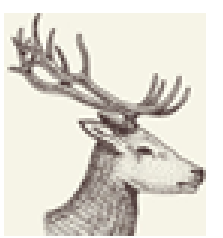

(fig.29) stag

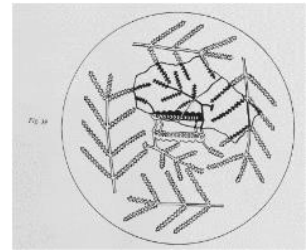

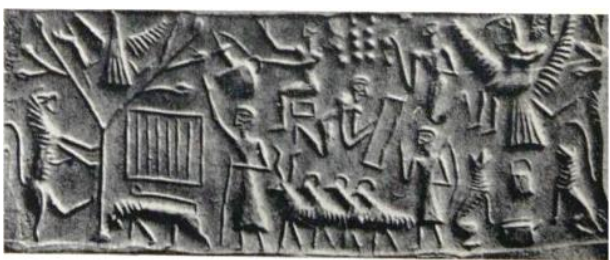

Boehmer1965 : no. 701

(fig.27)

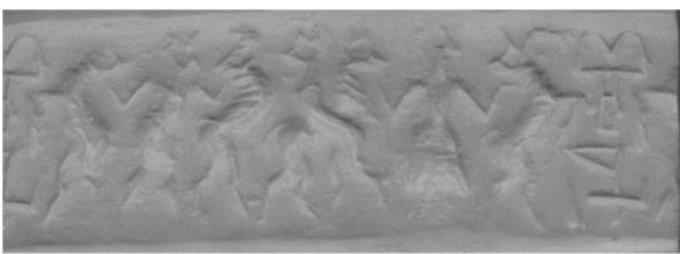

Wiseman.1962:no14d

(Fig28)

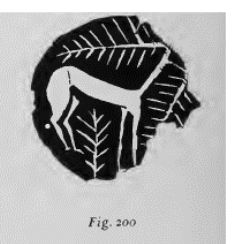

(fig.30) Goff.1963: fig 39; fig 200

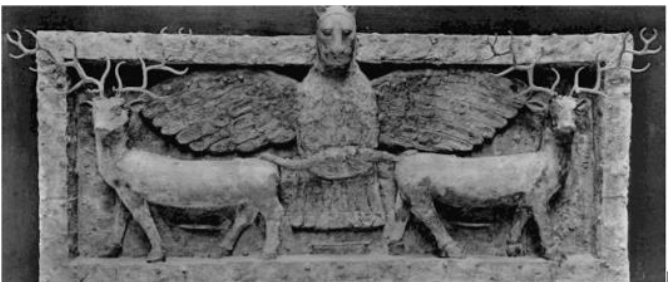

(fig.31) Hall ,1930 1 pl XI

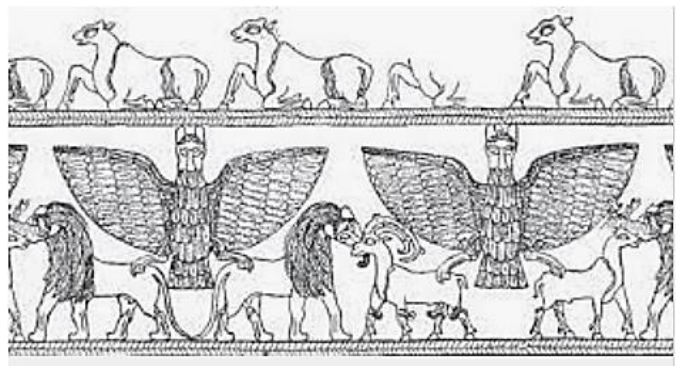

Ward,1910, fig56

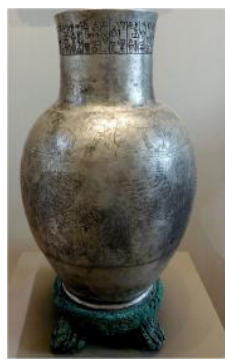

Musée du Louvre AO 2674

(Fig.32) 
The horns: symbol of power

\section{An iconographical study in Mesopotamian Art}

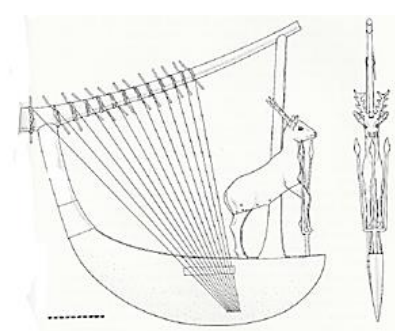

(fig.33) De Schaunsee 2002

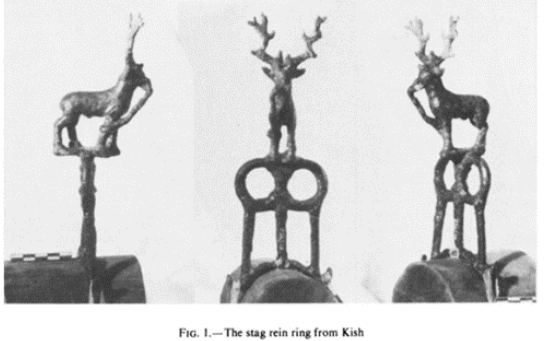

(fig.35)Müller-Karpe. 1985:fig 1

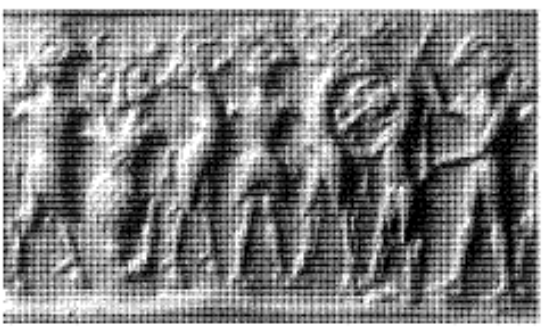

305

Buchanon.1981:no305

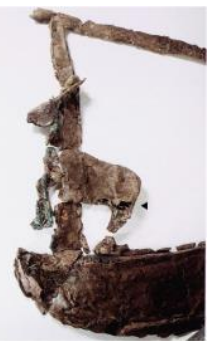

fig 6;pl17

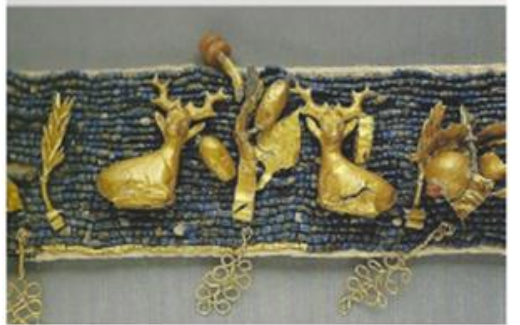

(fig.34)Chandler .2013:p39-40. img.21

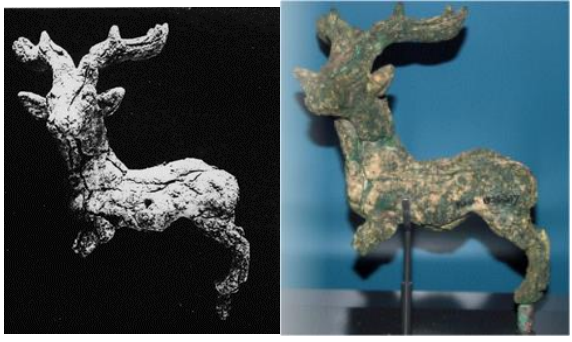

(fig.36) Langdon, 1924:p 92. pl. XXVIII

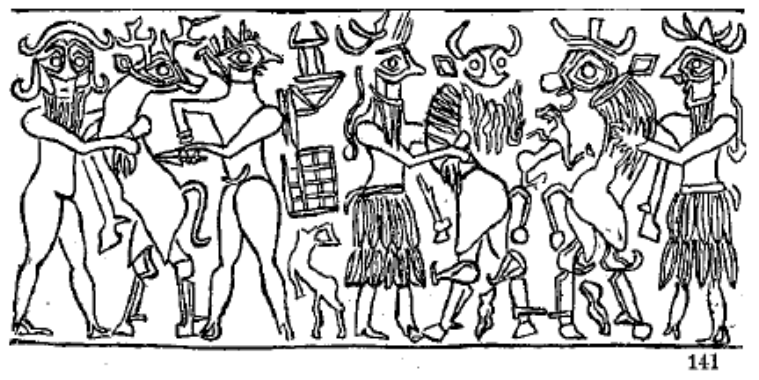

Ward,1910:no141

(Fig.37)

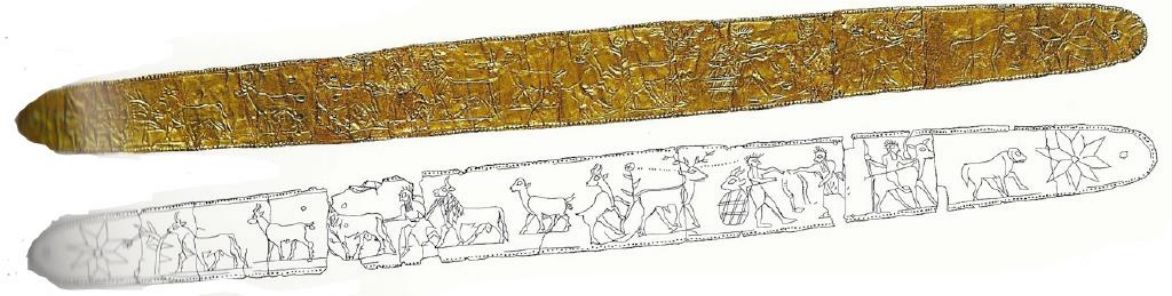

(fig. 38) Woolley ,1934; Chandler .2013

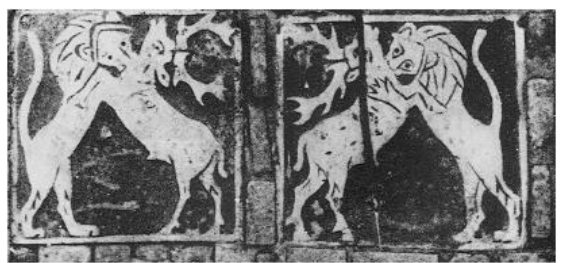

(fig39)

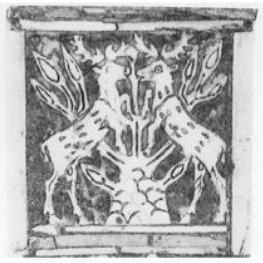

(fig40)

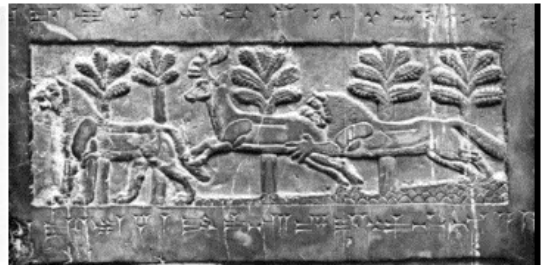

(fig.41) Moortagat. 1969.pl270- details

Woolley ,1934: pl 97-104 


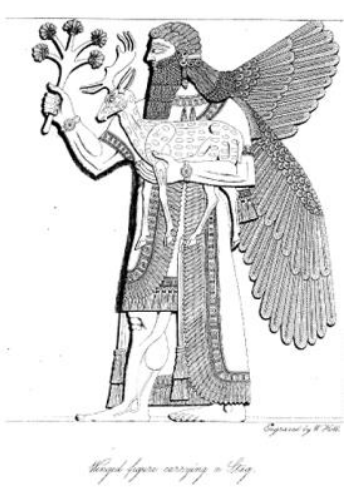

Layard.1853:pl 35 (detail)
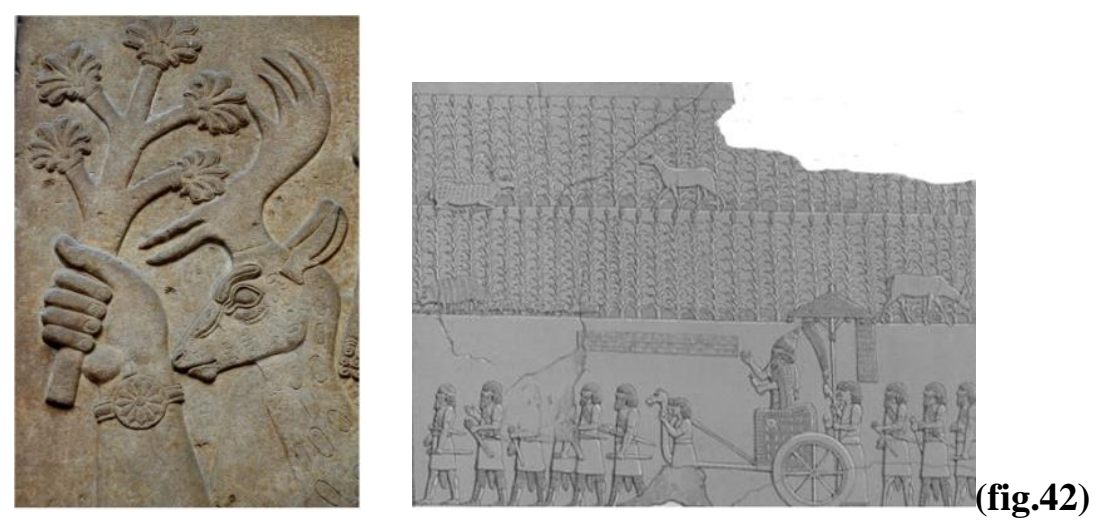

(fig.43) Layard,1853 :pl 12
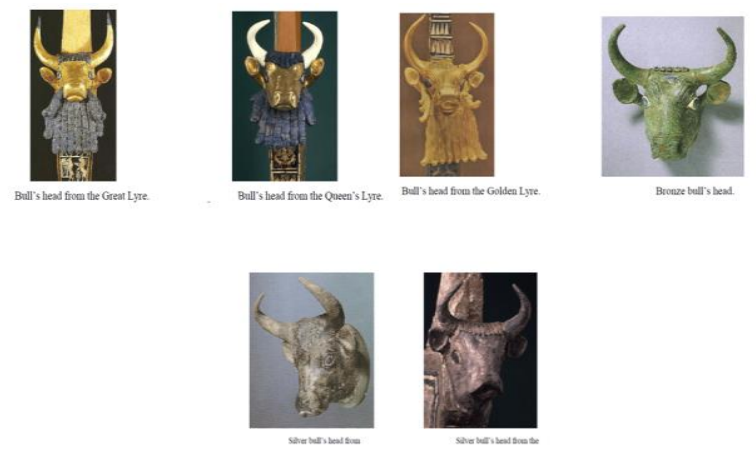

( fig.44) Van dijk .2011 figs.4-9

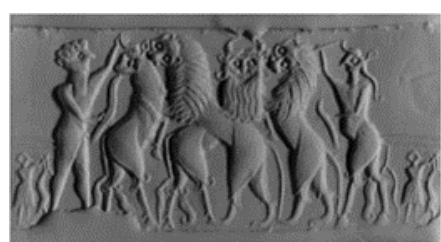

Wiseman 1962:,20-f
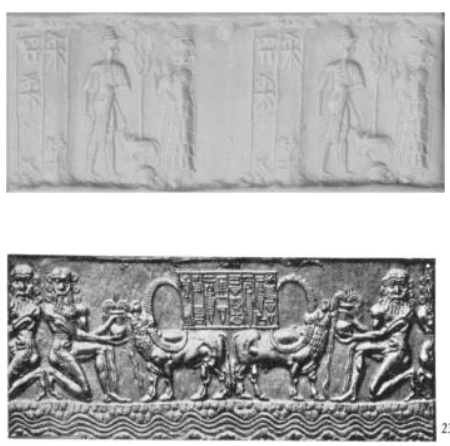

Boehmer.1965:no.232 von der Osten,1934: no 95 (fig.48)

(fig.46)

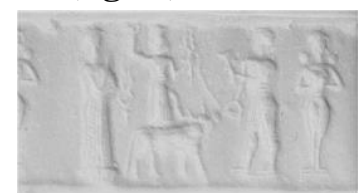

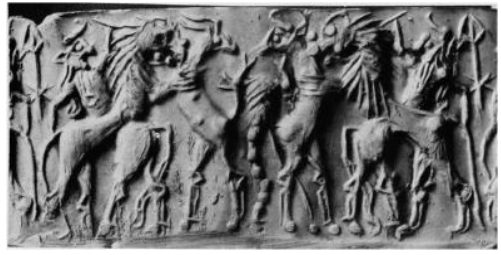

(fig.45) Schaunsee 2002:pl 20

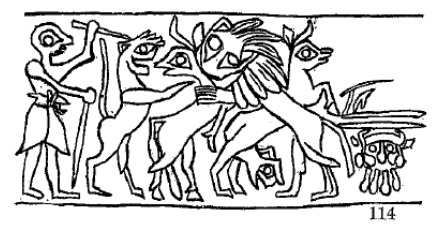

Ward.1910:no 114

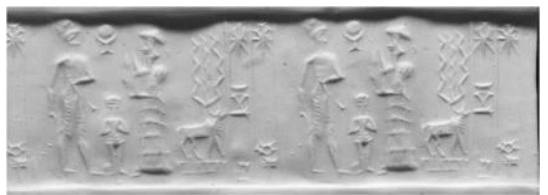

(fig.47) Collon.1986:245 - 449- 279

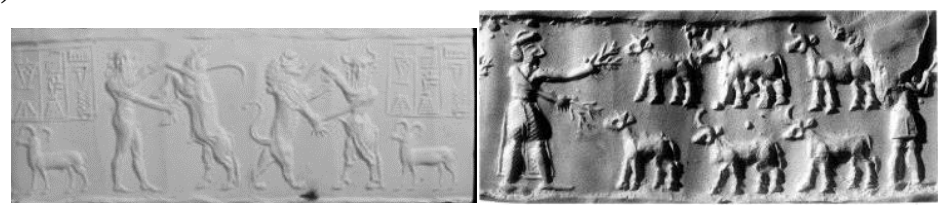

Buchanan, 1981:no. 143a.

(fig.49) 
The horns: symbol of power

An iconographical study in Mesopotamian Art

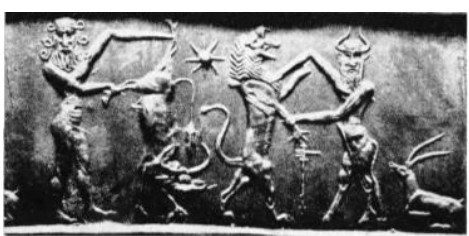

Boehmer 1965:no 230

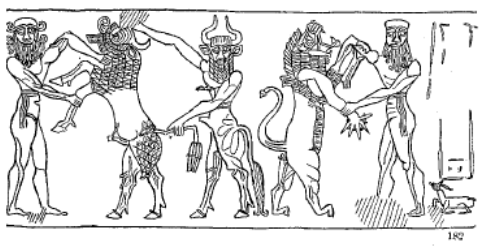

Ward.1910:no182

(fig.50)

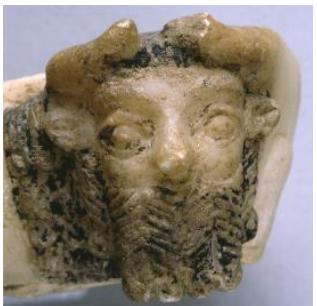

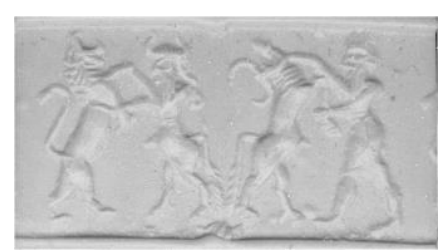

collon.1982:no93

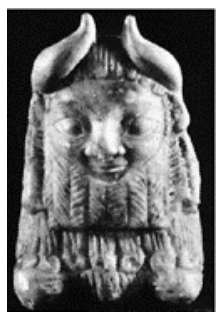

(fig.51)https://www.penn.museum/collections/object/322585 (fig.52) Frankfort.1943:49-B

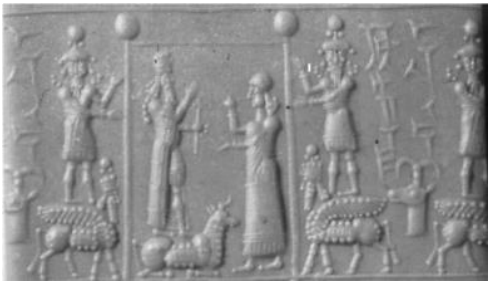

Watanabe.1993:no.7.6

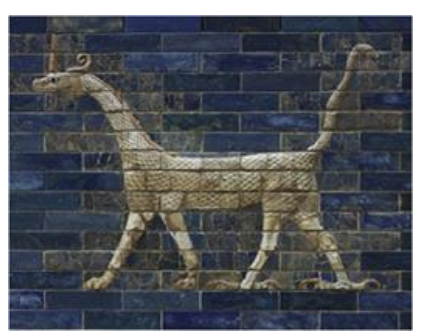

(fig 54) Watanabe 2015:fig 3

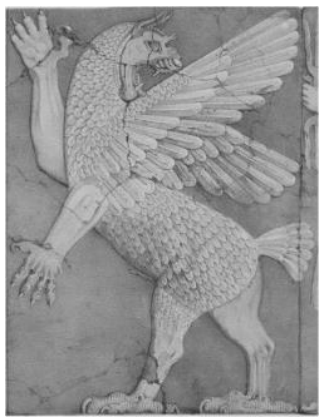

(fig.56)Lyard.1853:pl5

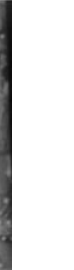




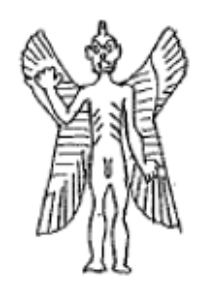

Pazuzu

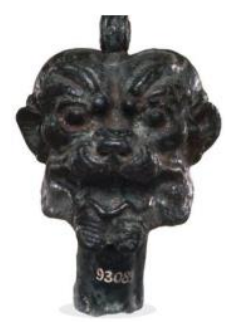

B.M 93089

Black\&Green .1992:p64

(fig.58)

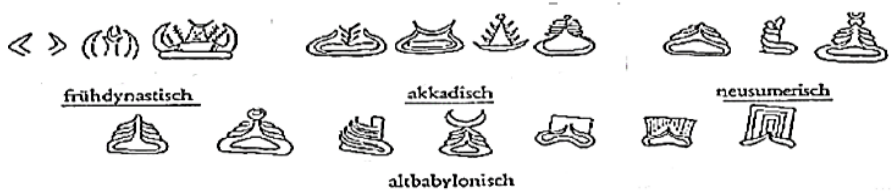

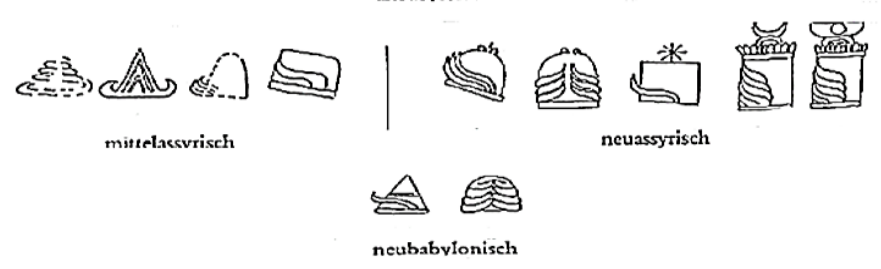

(fig.59) Boehmer 1972-1975

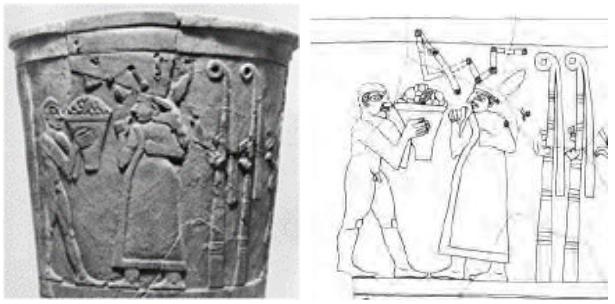

(fig.60)

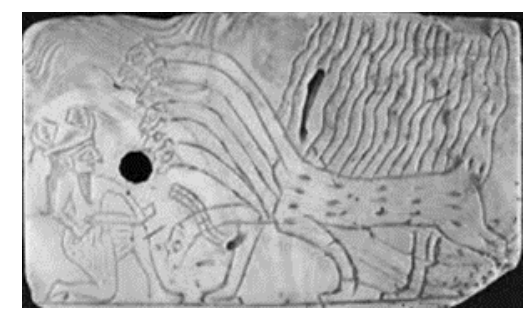

(fig.61)

Braun-Holzinger 2013: Tafel 1;tafel 11

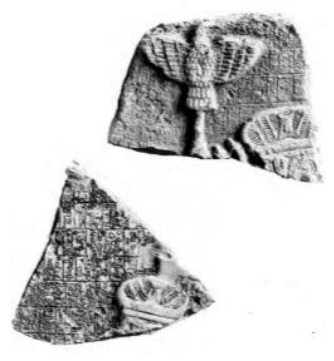

(fig.62) Braun-Holzinger 2013

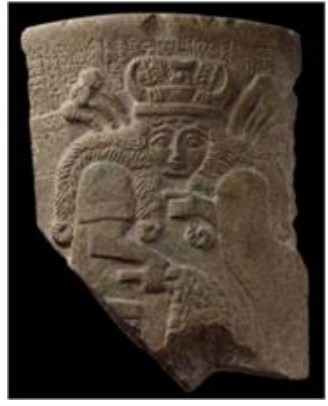

(fig.63) VA 07248 
The horns: symbol of power

An iconographical study in Mesopotamian Art

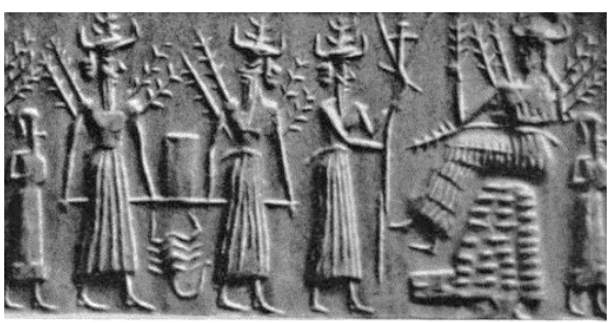

(fig.64)Boehmer,1965:no541

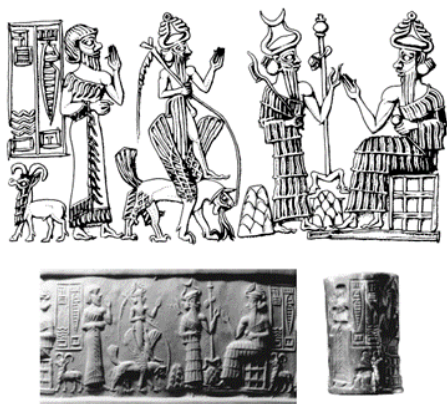

(fig.66) McMahon ,2006: pl.157/2

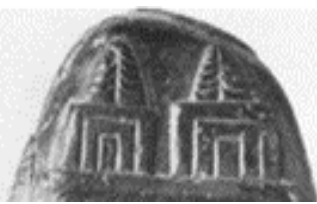

(fig.68)Seidl 1968:nr 86

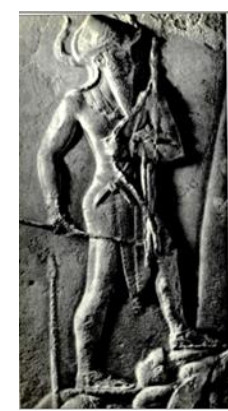

(fig .65) Moortgat, 1969: fig 156

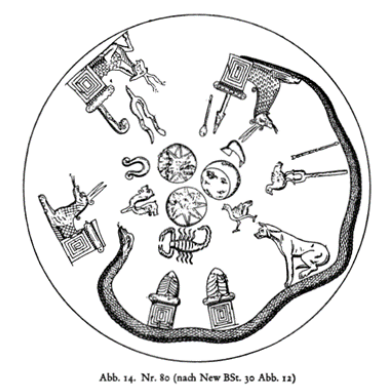

(fig.67) Seidl 1968:Abb14 .nr 80

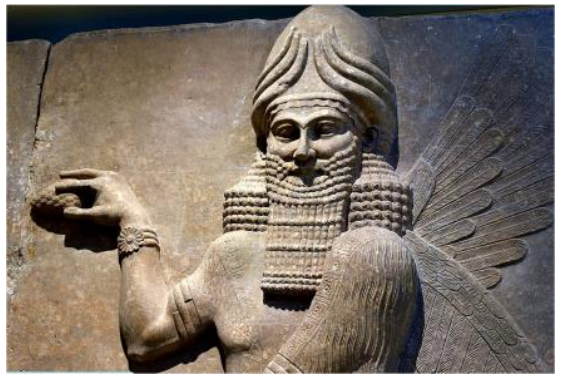

(fig.69) horned apkallu

https://commons.wikimedia.org/wiki/File:Humanheaded_and_winged_genie_or_apkallu,_from_Du rSharrukin,_Iraq,_c._710_BCE._Iraq_Museum

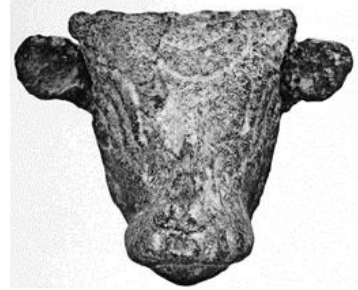

(fig.70) Hall,1930: pl.VII 


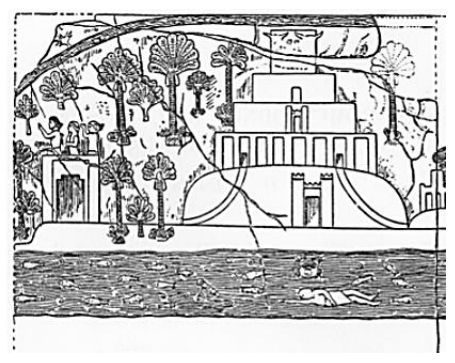

(fig.71) potts.1990: fig2

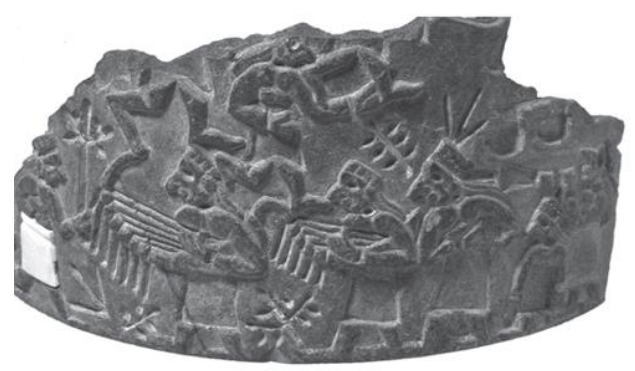

(fig.73) Wilson.2012:pl55

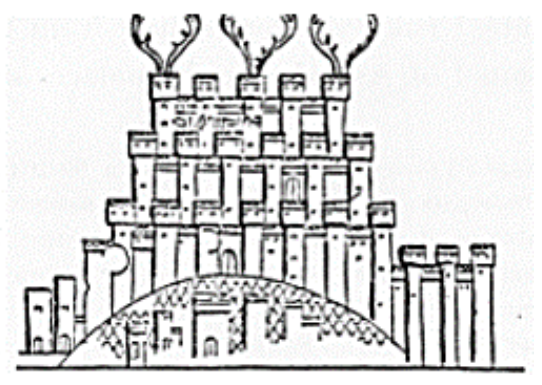

(fig.72) potts.1990: fig3

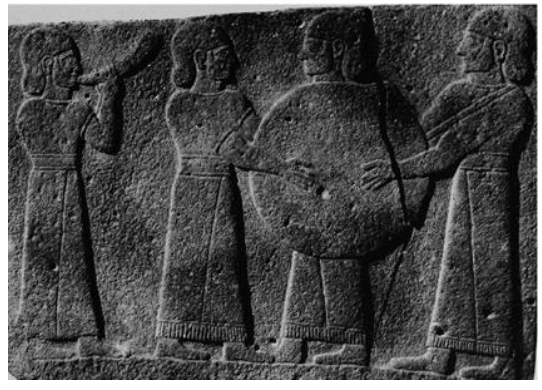

(fig.74) Woolley,1921: II, pl.18b 